OPEN ACCESS

Edited by:

Henry Wang,

University of Missouri, United States

Reviewed by:

Aiyuan Tao,

Shanghai Lixin University of Accounting and Finance, China

Ying Chen,

Guangxi University of Finance and

Economics, China

${ }^{*}$ Correspondence:

Zhanping Hu

huzhanping2006@163.com

Specialty section:

This article was submitted to

Sustainable Energy Systems and

Policies,

a section of the journal

Frontiers in Energy Research

Received: 10 May 2021

Accepted: 11 June 2021

Published: 06 July 2021

Citation:

Hu Z (2021) De-Coalizing Rural China:

A Critical Examination of the Coal to

Clean Heating Project from a Policy

Process Perspective.

Front. Energy Res. 9:707492.

doi: 10.3389/fenrg.2021.707492

\section{De-Coalizing Rural China: A Critical Examination of the Coal to Clean Heating Project from a Policy Process Perspective}

\author{
Zhanping $\mathrm{Hu}^{*}$ \\ School of Humanities and Social Sciences, North China Electric Power University, Beijing, China
}

This article critically examines the Coal to Clean Heating Project (CCHP) implemented in rural northern China from a policy process perspective. On the one hand, CCHP is an effective environmental policy that has reduced a large quantity of low quality bulk coal; on the other hand, however, it has created mounting socio-economic and political challenges, pushing the well-intended project into a deep dilemma. Moreover, existent discussions tend to attribute the dilemma to the "inappropriate implementation" of street-level bureaucrats. Through the lens of policy process, this article identifies key features of five critical temporal stages of CCHP: agenda setting, policy formulation, policy implementation, policy evaluation and policy adjustment. It illustrates that the policy process of CCHP has followed a politics-administration-dominated approach characterized by both positive attributes such as rapid resource mobilization and efficient implementation, and negative factors such as deficient policy design, overuse of mandatory instruments, and neglect of social acceptance. The major challenges that CCHP currently faces are identified, and policy implications are proposed based on the insights drawn from the policy process perspective. It concludes by highlighting the complexity of energy transition and the strength of linking energy transition research with a policy process perspective.

\section{Keywords: clean heating, double substitution, coal-to-gas project, coal-to-electricity project, policy process}

\section{INTRODUCTION}

The long-standing coal-dominated energy structure has made China the largest coal consumer in the world (Wang and Li, 2016), and also a prominent contributor to the severe air pollution in contemporary China (Ma et al., 2017; Xie et al., 2020). Among multiple patterns of coal usage, civil bulk coal, a type of low quality and unprocessed raw coal, consumed by rural households, was found to be particularly harmful to air quality in northern China (Liu et al., 2016; Zhang et al., 2017; Xie et al., 2020). To tackle the air quality crisis, China initiated an ambitious and arguably the toughestever action plan, Air Pollution Prevention and Control Action Plan, in 2013. One critical section of

\footnotetext{
Abbreviations: BTH, Beijing-Tianjin-Hebei region; CAE, Chinese academy of engineering; CCHP, coal to clean heating project; CTG, coal-to-gas; CTE, coal-to-electricity; MEE, ministry of ecology and environment; MF, ministry of finance; MHURD, ministry of housing and urban-rural development; NEA, national energy administration; NDRC, national development and reform commission; $\mathrm{PM}_{2.5}$, particulate matter with an aerodynamic diameter of less than 2.5 microns.
} 
the 2013 Action Plan is CCHP, a state-sponsored energy project aiming to radically transform the coal-dominated heating energy structure to cleaner energies (e.g., natural gas, electricity, centralized heating systems, as well as renewables such as solar) in northern rural China.

Since its first appearance in the 2013 Action Plan, CCHP has been implemented, sporadically at the beginning but intensively since 2017, for eight years in China so far. As of 2020, more than twenty five million rural households have been taken into the mega project (MEE, 2020a). 43 municipal cities from BTH and other key regions of air pollution have been selected as pilot sites for CCHP. The progress appears exceptionally remarkable. As a de facto environmental policy, CCHP has contributed significantly to air quality improvement (Zhang et al., 2019a; Zhang et al., 2020). Li Ganjie, the former Minister of MEE, claimed that the CCHP contributed approximately one third to the improvement of air quality in northern China (Li, 2018). However, despite the encouraging environmental effects, grave challenges have been exposed in recent years, including insufficient and unstable energy supply, unbearable energy costs, and brutal behaviors of street-level bureaucrats in implementation, which have been dragging this mega project into a deep dilemma and uncertainty. Numerous comments and reports from social media and governmental systems regarding the current situation of CCHP center on the dimension of implementation, taking the misbehaviors of local implementers as the major reason for the dilemma (An, 2017; Chu, 2018; Zhao, 2021).

The brutal and "one-size-fits-all" behaviors of street-level bureaucrats surely should be criticized, while overemphasis on it would obscure the flaws of the entire policy system. The persistent exposure of social dissatisfaction and mounting queries about the design of the project since 2017 have pointed to more complicated problems beyond the misbehaviors of local officials. Academic literature has not attended to this issue systematically, although researchers have started to evaluate the effectiveness of the project based on specific locations with different evaluation parameters (Wang et al., 2019a; Barrington-Leigh et al., 2019; Zhang et al., 2019b; Gong et al., 2020; Hu, 2020; Wu et al., 2020; Yan et al., 2020).

Furthermore, energy transition studies in general have mostly focused on specific policy stages or policy output through policy content analysis, and regrettably neglected the critical implication of long-lasting, politically contested policy process (Kern and Rogge, 2018). An explicit consideration of policy process is particularly instrumental to understanding the impacting factors of policy instruments and innovations, the causal link between policy-making and policy implementation, as well as to develop well informed policy recommendations (Grossman, 2015; Thomas, 2016; Kern and Rogge, 2018).

Given that gap, this article, from the lens of policy process, critically examines the evolutionary process of CCHP, and identifies defining features of five critical sub-stages: agenda setting, policy formulation, policy implementation, policy evaluation and policy adjustment. The lens of policy process allows us to challenge the prevailing discussions that attribute the current dilemma to the poor implementation of local bureaucrats.
Instead, this study contends that the whole project was built on a poorly articulated and integrated policy framework, and without thorough reflection and adjustment of the whole policy process, the likelihood of achieving successful transition by CCHP remains grossly challenging.

The data utilized in this article stem from three sources. The first source is the policy documents associated with CCHP at different levels of administrations, which can provide valuable information about the policy design and adjustments. For data collection, policy documents from national-level administrations were collected through searching major governmental websites, covering the State Council, MEE, NEA, and NDRC, among others. For local governments, given the vast diversity, Beijing Municipality and Hebei Province, two typical regions for CCHP, were selected as representatives to collect local policy documents. More than fifty policy documents from various administrations associated with CCHP ranging from 2013 to 2020 were collected.

The second source is reports and commentaries from social media, which can provide valuable information about the social feedback and interactions between government and the society during the rollout of CCHP. For official media sources, People's Daily, Xinhua Net, China Energy News, and China Environment News, among others, were consulted; for independent media, Caixin, Beijing News, and Southern Weekly, among others, were consulted. In addition, since 2017 the author has intentionally accumulated news and reports associated with the issue from multiple sources, including social network apps, such as Weibo and Wechat. After phasing out repetitive contents, over one hundred of original reports and commentaries were collected. The third source is peer-reviewed papers and academic reports. The author searched both international and domestic academic databases to acquire a complete literature of CCHP. For international literature, two major databases were searched: Web of Science and Scopus, with key words associated with CCHP, i.e., "coal to gas", "coal to electricity", "coal substitution", "double substitution", "bulk coal control", "clean heating", and "China", ranging from 2013 to 2020. Searching results show that over two hundred articles focus on the technological aspects of heating devices, and only about thirty peer-reviewed English papers that study the policy aspects of CCHP. For domestic literature, the author searched the largest database, China National Knowledge Infrastructure (CNKI), ranging from 2013 to 2020 , and acquired more than thirty peer-reviewed papers associated with CCHP. This set of data is also supplemented by a dozen of survey reports published by university researchers and independent NGOs. The author believes these three sets of data are sufficient enough to evaluate the CCHP project in an overall sense. Nonetheless, limitations deserve to be mentioned. CCHP has been implemented in highly heterogeneous contexts across nearly ten provincial level regions and tens of prefecture-level cities. Therefore, local variations, particularly in the stage of policy implementation, must to a varying degree exist, which however are not discussed in this paper.

The article is organized as follows. Historical Background and Practical Progress of Coal to Clean Heating Project briefly introduces the overall background and progress of CCHP. The Policy Process of Coal to Clean Heating Project provides an 


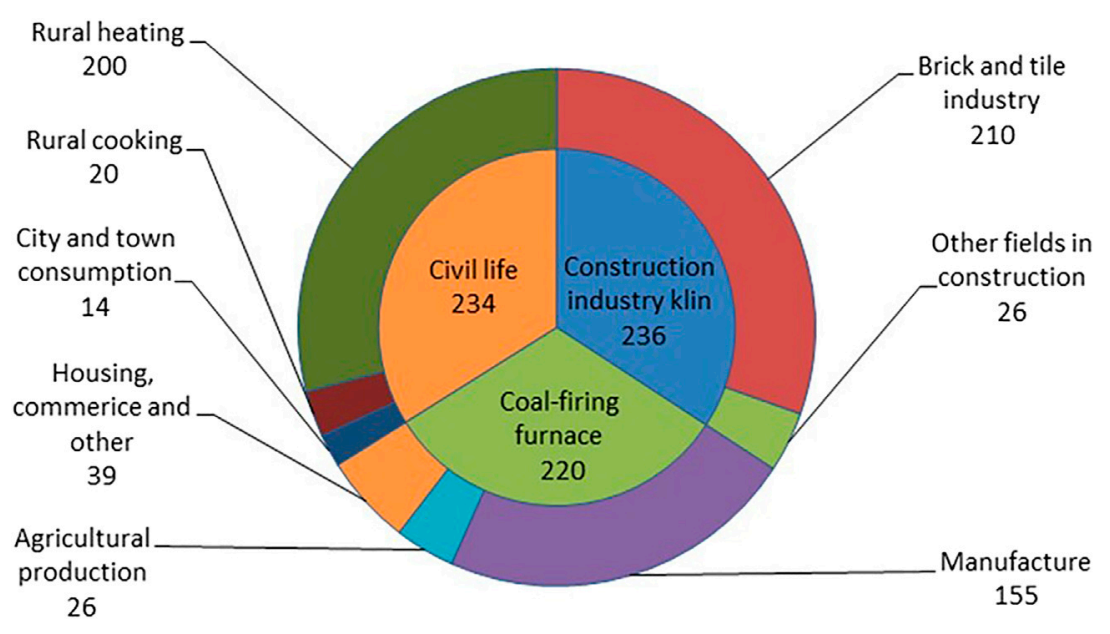

FIGURE 1 | Major sources and constituent structure of Chinese bulk coal (Unit: Million Tonnes). Data Source: Adapted From (He and Li, 2017).

analysis of CCHP from the policy process perspective, according to the five policy stages. Based on the analysis, Policy Implications: Insights From the Policy Process Perspective proposes relevant policy implications drawn from the insights of the policy process perspective. Conclusion concludes the article with an emphasis of the complexity of energy transitions and a call for linking energy transition research with a policy process perspective.

\section{HISTORICAL BACKGROUND AND PRACTICAL PROGRESS OF COAL TO CLEAN HEATING PROJECT}

\section{The Historical Background of Coal to Clean Heating Project}

$\mathrm{CCHP}$ is derived from the deterioration of air quality in the BTH region since the beginning of the 2010s, when heavy smog provoked mounting and fierce public discontent (Wang, 2013; Aunan et al., 2018). Identifying the causes of and solutions to the heavy air pollution has become the most popular research subject since the severe smog events in 2013 (Wang, 2013; Xu et al., 2013). Among various findings, coal was universally identified as one of the primary causes for the increased level of $\mathrm{PM}_{2.5}$-one of the major constituents of smog in northern China (MEE, 2019). Furthermore, among different patterns of coal consumption, bulk coal consumed in winter heating by rural households was found as one direct reason for heavy smog during winter season (MEE, 2019). As estimated, the quantity of civil bulk coal in rural regions amounted to 220 million tonnes in 2015, taking up $94 \%$ of national civil bulk coal consumption ( $\mathrm{He}$ and $\mathrm{Li}, 2017$ ) (see Figure 1). Of the bulk coal consumption for rural civil life, over $90 \%$ is used for residential heating. Moreover, rural heating bulk coal was found to contribute $30-50 \%$ of $\mathrm{PM}_{2.5}$ concentration in northern China during autumn-winter season (Wang Z et al., 2019b).

To improve air quality, bulk coal for rural heating must be reduced significantly ( $\mathrm{He}$ and $\mathrm{Li}, 2017$ ). Since 2013, particularly from 2017, an array of national initiatives and policies have been launched to direct, guide, and regulate the implementation of CCHP in northern China, particularly in the BTH and surrounding regions, including Shanxi, Henan and Shaanxi provinces. Correspondingly, multilevel regional and local governments issued numerous regional plans and concrete measures to execute the grand project. In terms of nationallevel polices, as Table 1 shows, a comprehensive policy package has been enacted by national-level administrations, including general national plans, sectoral plans from MEE and NEA, ad hoc working schemes, and supportive policies. Local governments at different levels were requested to issue corresponding plans and polices. As a result, within a short timeframe, a comprehensive and systematic policy package has been established to promote CCHP (as illustrated by Figure 2).

\section{The Progress of Coal to Clean Heating Project in Practice}

In practice, it was only until 2017 that CCHP started to be promoted by local governments in an intensive manner. Between 2013 and 2016, most local governments from northern China focused on policy measures such as transportation regulations and coal reduction and replacement in industrial sectors. Only a limited number of cities took efforts to conduct CCHP during this period. Due to its special political position and severity of air pollution, Beijing Municipality pioneered in bringing CCHP into practice. In 2013, Beijing initiated a special action plan in its rural area: "Reduce Coal to Exchange Clean Air", of which CTE project was an important constituent part. From 2015, Beijing and a few cities from Hebei Province (such as Shijiazhuang and Xingtai) started to initiate CTG pilot projects. Nonetheless, the implementation of CCHP was largely conducted in a sporadic and tentative manner before 2017 .

As the assessment year of the 2013 Action Plan, 2017 was a critical time for CCHP. Local governments faced tremendous 
TABLE 1 | Summary of major national level policy documents regarding CCHP.

Time Policy title

2013 Air pollution prevention and control action plan.

2014 Temporary measures of coal consumption reduction and substitution management in the key regions.

2016 'Thirteenth five year plan' of energy-saving and emission-reduction comprehensive working scheme.

2016 'Thirteenth five year plan' of ecological and environmental protection.

2016 'Thirteenth five year plan' of energy development.

2016 BTH air pollution and control strengthening measures.

2017 Report on the work of the central government.

2017 Working scheme of BTH and surrounding area air pollution prevention for 2017.

2017 Action scheme of comprehensive governance of autumn and winter air pollution in BTH and surround area (2017-2018).

2017 Winter clean heating plan in Northern China (2017-2021).

2017 Instructions of clean heating price policy in Northern China.

2017 Notice on selecting pilot cities of CCHP supported by central finance in Northern China.

2017 Notice on conducting well the work of 'coal-to-electricity' to ensure people a warm winter in Northern China.

2018 Document No.1 of the central government: Instructions of enforcing the strategy of rural vitalization.

2018 Three-year action plan of winning Blue Sky protection campaign.

2018 Action scheme of comprehensive governance of autumn and winter air pollution in BTH and surrounding area (2018-2019).

\section{Contents regarding CCHP}

Enhance the provision of clean energies and control coal consumption.

By 2015, build new gas pipes able to convey 150 billion $\mathrm{m}^{3}$.

Promote gas substitution of coal in residential sector.

Enhance the energy efficiency of residential properties in Northern China

By 2017, the inhalable particulates of BTH and surrounding areas should reduce

25\% compared to 2012.

By 2017, Beijing should reduce 12 million tonnes of coal consumption based on the quantity of 2012, Tianjin 10 million, Hebei province 40 million, Shandong province 20 million.

The governments of the key regions should formulate concrete coal reduction and substitution action schemes, which should include CCHP.

'Plan firstly, develop secondly', orderly promote 'coal-to-gas' and 'coal-toelectricity' programs.

Transform energy structure, and promote clean energies.

Reduce bulk coal usage and promoting coal-to-gas and coal-to-electricity substitution in residential heating.

By 2020, coal consumption is reduced to $58 \%$ of overall energy consumption. Promote substitution of bulk coal in northern China, and implement 'coal-to-gas' and 'coal-to-gas' projects in BTH and surround areas.

Take comprehensive measures to reduce bulk coal usage.

Promote gas, electricity, cleaner coals and renewables to replace bulk coal. Reform gas price mechanism to reduce gas cost and promote coal-to-gas substitution.

Enforce electricity substitution project.

Promote rural CTG and CTE projects in BTH region.

By the end of October, 2017, all the plain area of Beijing should be de-coalized. Strengthen the efforts of tackling pollution from fire coal, comprehensively addressing bulk coal.

Accomplish three million households of double substitution in 2017.

Take $2+26$ cities as the first group of CCHP implementation region.

Set Beijing, Tianjin, Baoding and Langfang as 'zero coal' area.

By the end of October 2017, every city should finish CCHP covering

50,000-100,000 households.

Beijing, Tianjing and four provinces should finish coal-substitution for 3.55 million rural families by the October of 2017.

Take measures to forbid re-ignition of bulk coal in regions already covered by $\mathrm{CCHP}$.

By 2019, the clean heating rate of northern China should be over 50\%, reducing 70 million ton of bulk coal; by 2021, cleaning heating rate of Northern China should be over $70 \%$, reducing 150 million ton of bulk coal.

Local governments should promote differential strategies based on specific endowments, and avoid 'one-size-fits-all' approach.

Promote differential prices.

Price subsidies to rural residents.

Tax preferences to enterprises that provide heating services to rural residents. Select pilot cities for clean heating projects.

$2+26$ corridor cities as the key targets.

Provide 3 year long financial support for pilot cities at differential scales: one billion Yuan for province-level municipality; 700 million for provincial capital city; 500 million for prefecture-level city.

Take efforts to make sure rural residents have a warm winter.

Stabilize the provision of electricity in the rural areas conducting 'coal-toelectricity' switch.

Accelerate construction and upgrade of rural electric grid.

Promote coal-replacing programs in Northern rural China.

Effectively promote clean heating in Northern China with case-by-case principle. By the winter season of 2020 , the BTH and surrounding areas and the pain areas of Fen-Wei River should finish substitution of coal with clean energies.

Encourage to improve energy efficiency of rural houses.

Expand financial support for CCHP.

Local governments should make a three-year action plan to accomplish policy goal of zero-coal by 2020 in plain villages.

Implementing project based on flexible principle, choosing technological approach based on local concrete situation.

(Continued on following page) 
TABLE 1 | (Continued) Summary of major national level policy documents regarding CCHP.

\begin{tabular}{|c|c|c|}
\hline Time & Policy title & Contents regarding CCHP \\
\hline 2018 & Notice on expanding pilot cities of CCHP supported by central finance. & $\begin{array}{l}\text { Bring most of } 2+26 \text { cities, Zhang Jiakou city, cities from Fenwei plain into the } \\
\text { range of pilot city program. } \\
\text { Provide RMB } 500 \text { million subsidy for Zhang Jiakou city, } 300 \text { million for cities from } \\
\text { Fenwei plain. } \\
\text { After three years, the urban clean heating rate amounts to } 100 \% \text {; civil bulk coal in } \\
\text { plain area should be generally replaced. }\end{array}$ \\
\hline 2019 & Report on the work of the government (2019). & $\begin{array}{l}\text { Significant achievement on coal-to-gas and coal-to-electricity projects in } 2018 . \\
\text { Continue working on clean heating in Northern China, and meanwhile guarantee } \\
\text { people to have warm winter. }\end{array}$ \\
\hline 2019 & Notice on mid-term evaluation of clean heating in Northern China. & $\begin{array}{l}\text { Check the progress of local governments on CCHP from } 2016 . \\
\text { Summarize the experiences and problems in CCHP implementation. }\end{array}$ \\
\hline 2019 & $\begin{array}{l}\text { Action scheme of comprehensive governance of autumn and winter air pollution } \\
\text { in BTH and surrounding area (2019-2020). }\end{array}$ & $\begin{array}{l}\text { By the end of October, } 2019,2+26 \text { cities should finish double substitution of } \\
5.24 \text { million rural families. } \\
\text { Before the heating season of } 2019 \text {, the first trial cities funded by central finance } \\
\text { should accomplish the task of double substitution. } \\
\text { Promote double substitution in the unit of county or town, instead of scattered } \\
\text { villages. } \\
\text { Take various efforts to stop re-burning of coal in areas already substituted. } \\
\text { Ensure substituted families receive subsidies timely and sufficiently. }\end{array}$ \\
\hline 2019 & $\begin{array}{l}\text { Action scheme of strengthening inspection and conducting designated } \\
\text { assistance in the key regions of Blue Sky Protection Campaign. }\end{array}$ & $\begin{array}{l}\text { Strengthen the inspection of the implementation of air quality improvement } \\
\text { policies. } \\
\text { Evaluate both environmental goals and the working process. } \\
\text { Conduct comprehensive check and verification of local working progress } \\
\text { regarding coal-to-gas and coal-to electricity heating projects. }\end{array}$ \\
\hline 2020 & $\begin{array}{l}\text { Action scheme of comprehensive governance of autumn and winter air pollution } \\
\text { in BTH and surrounding area, and Fenwei River plain (2020-2021). }\end{array}$ & $\begin{array}{l}\text { Before the heating season of 2020, } 7.09 \text { million rural households should be taken } \\
\text { into CCHP. } \\
\text { In the areas that have been covered by CCHP, local governments should be } \\
\text { designated as zero-coal zone. Coal re-burning is strictly forbidden in these areas. } \\
\text { Guarantee the supply of natural gas and electricity for clean heating households. } \\
\text { Without a trial season, the coal facilities of rural households should not be } \\
\text { removed. } \\
\text { Provide price support for heating gas and electricity in winter season. } \\
\text { Practice differential subsidy policies, focus on poor households in rural areas. }\end{array}$ \\
\hline
\end{tabular}

political and administrative pressure to accomplish the environmental targets set by the Plan. Meanwhile, the central government started to offer financial support to enforce CCHP, which provided strong incentives for local governments to grasp the opportunity to rapidly enforce implementation. Driven by multiple factors, local governments have acted very aggressively from 2017, with the achieved quantities significantly exceeding the planned goals, as shown by Figure 3. The four-year rollout has taken over 25,000,000 rural households from northern China into CCHP (He and Li, 2020). By the end of 2020, all the plain villages in Beijing have been covered by CCHP. Hebei Province alone has promoted CCHP to approximately eight million rural households by 2020 . Among the multiple technological models, CTE and CTG are the two dominant ones, taking up more than $90 \%$ ( $\mathrm{He}$ and $\mathrm{Li}$, 2020).

Besides, the geographical scope of CCHP targeting area has been expanded rapidly. In 2017, BTH and surrounding areas (i.e., Shandong, Shanxi and Henan provinces) were the key regions, and 28 cities i.e., the $2+26$ air convey corridor cities, from these regions were set as the key cities of clean heating transition. In 2018, Fen-Wei River Plain Area in western China (including 11 cities from Shanxi Province and Shaanxi Province) was taken into the list. Moreover, the central government selected cities for policy experimentation, and the number of pilot cities has kept expanding from 12 in 2017 to 43 in 2019 ( $\mathrm{He}$ and $\mathrm{Li}$,). The financial support from the central government for pilot cities has also increased dramatically from RMB 7.8 billion in 2017 to 15.2 billion in 2019 (Ministry of Finance (MF), 2020); the financial expenditure from local governments has been much more than that from the central government. From 2017 to 2018, the subsidy funding from local governments for CCHP was up to RMB 55.5 billion, over twice more than that from the central government (He and Li, 2019).

With rapid advance, CCHP has made considerable contribution to bulk coal reduction and air quality amelioration. CCHP facilitated to reduce approximately 100 million tonnes bulk coal by the end of 2019 (MEE, 2020b). Meanwhile, air quality improvement has been well observed (see Figure 4). Compared to 2013, the $\mathrm{PM}_{2.5}$ concentration of $\mathrm{BTH}$ and surrounding areas in 2017 has reduced by $40 \%$, surpassing $25 \%$ of the target set by the 2013 Action Plan (Wang et al., 2019a). Besides, observable health effects of reducing indoor pollution created by bulk coal have also been reported (BarringtonLeigh et al., 2019; Wu et al., 2020). 


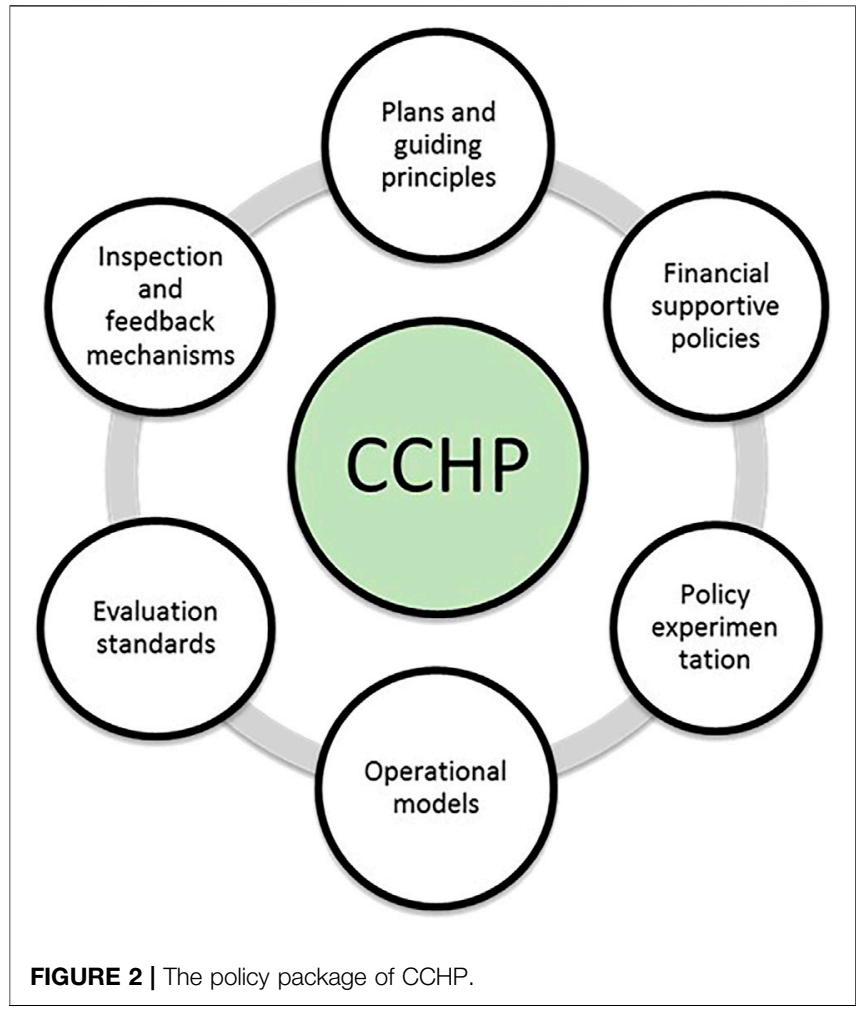

However, the rapid progress has been accompanied by numerous problems and doubts since the winter of 2017. Issues about energy security, weak social acceptance, technological immaturity and the most heatedly reported inappropriate implementation by local governments, among others, have been constantly exposed and pushed the mega project into deep dilemma. The project through an incorporation with the framework of policy process will be critically discussed in next section.

\section{THE POLICY PROCESS OF COAL TO CLEAN HEATING PROJECT}

Policy process is broadly defined as an analytical framework encompassing different policy stages and driving variables (Sabatier and Weible, 2014). A multiplicity of theoretical frameworks have been developed to understand the complexity of policy processes (Kern and Rogge, 2018). This article does not intend to focus on any specific policy stage or variable from a singular theoretical perspective, but takes the policy process as a systematic framework composed by a couple of interconnected and integral parts (Wu et al., 2010; Kern and Rogge, 2018). Confronted with increasingly complex and challenging socio-political environments, achievement of policy goals entails integrated policy processes that coherently and systematically link different parts of policy processes (Wu et al., 2010). Given that justification, this article examines the features of five key stages of CCHP's policy process: 1) agenda setting, 2) policy formulation, 3) policy implementation, 4) policy evaluation and 5) policy adjustment. This approach illustrates that CCHP has been poorly articulated in the policy process and requires thorough and systematic reconsideration and readjustments. Merely focusing on the implementation section, i.e. blaming the "inappropriate behaviors" of local implementers, offers little help in improving the effectiveness of CCHP in the future.

\section{Agenda Setting}

Agenda setting is the initial stage of a typical policy process. At this stage, potential public problems are identified and confirmed, and then attempt to catch political attention, so that specific public policies enter into the agenda list of decision-makers. The agenda setting of China's public policies has followed multiple models contingent upon varied spatiotemporal contexts (Wang et al., 2019b; Yang

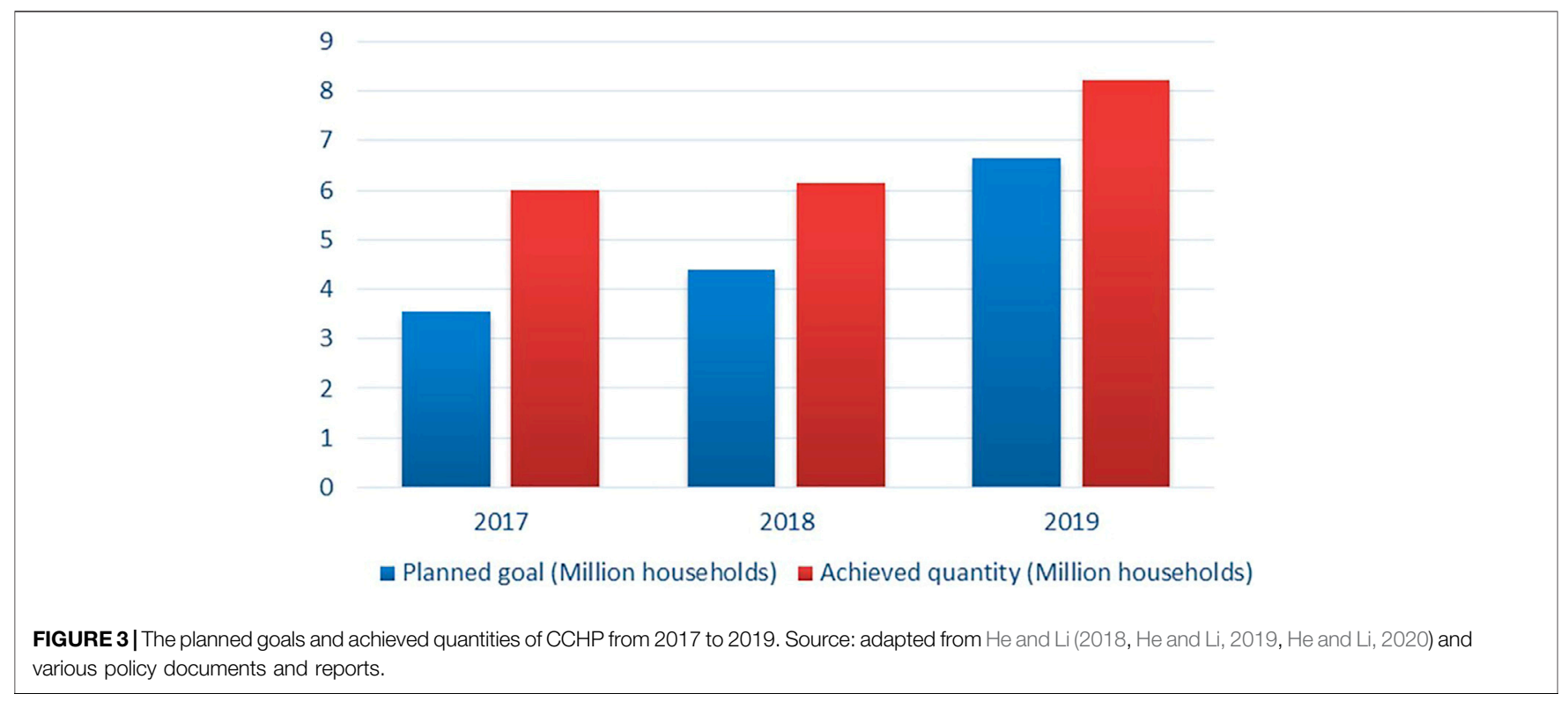




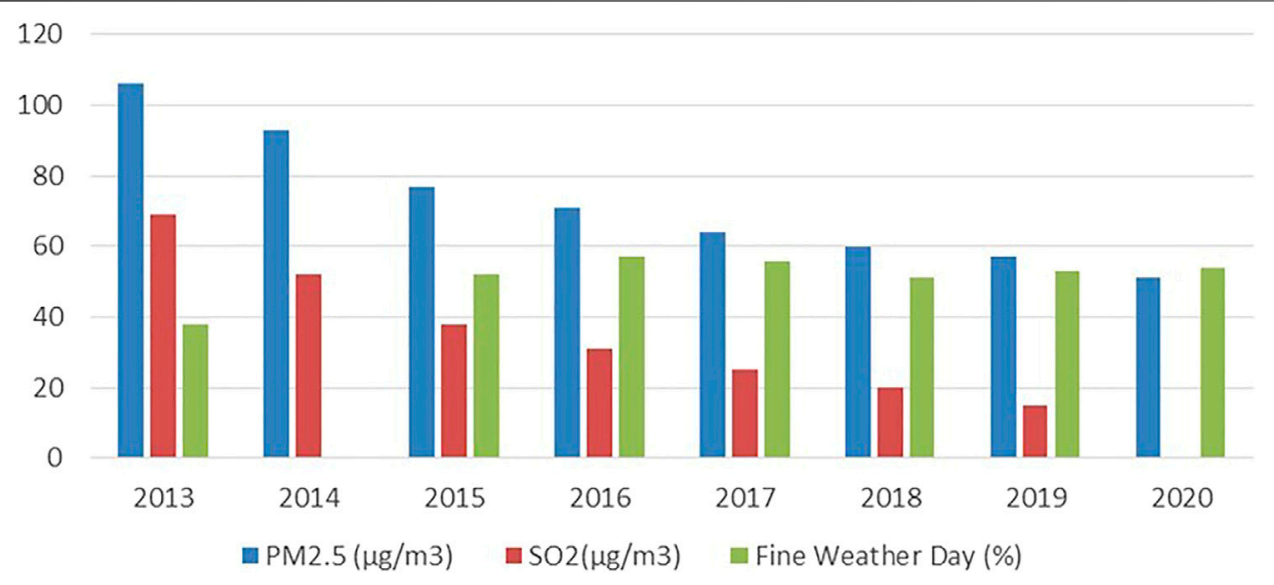

FIGURE 4 | Key indicators of air quality improvement in BTH and Surrounding Areas from 2013 to 2020. Source: adapted from MEE Annual Report (2013-2020).

and Li, 2019; Zhao and Xue, 2017). Wang (2008) argued that public policies in China have taken multiple agenda setting models according to different situations, and currently a popular-pressure model has become increasingly prevalent. In this model, powerful public pressure pushes decision-makers to respond promptly, with solutions quickly formulated and rolled out. The proposal of bulk coal reduction was triggered by air quality crisis in northern China, which was so severe that acute public discontent was produced, ultimately taking air pollution mitigation into the political agenda (Aunan et al., 2018). From 2013, ameliorating air quality as rapidly as possible has become a national imperative which needs to be tackled at all costs (Jin et al., 2016). With support from associated scientific research, replacing coal with clean energies became a logical and plausible roadmap (He and Li, 2017; Wang Z et al., 2019b). In this sense, air pollution mitigation measures are a set of responsive actions to public pressure, and CCHP was taken as an integral part of these actions. One critical issue in the agenda setting of CCHP is an evident mismatch between those who pushed it to political agenda (mostly well-educated middle class from first-tier cities, such as Beijing) and those who are mostly affected by its implementation (e.g. rural residents) (Cao and $\mathrm{Hu}, 2019 ; \mathrm{Hu}$, 2020). The voice of rural residents-a silent and weakly represented social group in China-failed to enter into the agenda setting, which left grave repercussions for subsequent policy processes. To a certain degree, popular pressure can be powerful in prioritizing public agenda, but can also be vague in policy design, which may jeopardize policy effectiveness eventually (Wang, 2008; Zhao and Xue, 2017). As widely found in China, hasty agenda setting driven by political concerns often results in deficient policy design, partial policy goals, short-termism in implementation, and ignorance of deepseated social problems (Wang, 2008; Wu et al., 2010; Zhao and Xue, 2017). As shown below, the agenda setting of CCHP prioritized environmental concerns over other concerns such as technological suitability, social acceptance, and energy security, among others, which buries "time bombs" for subsequent policy implementation.

\section{Policy Formulation}

Policy formulation is the process that how solutions to some public issues are sought and formulated, which results in promulgation of specific forms of policy output (Wu et al., 2010). Here three key aspects of the policy formulation of CCHP are discussed: the first is about how specific technological models, i.e., CTG and CTE, were taken as the major solution; the second asks what were the policy objectives of CCHP and how they were set; and the third presents how policy experimentation, a distinctive model of China's policy process, worked in the policy formulation of CCHP.

\section{Selection of the Dominant Technological Models}

As reviewed in Historical Background and Practical Progress of Coal to Clean Heating Project, CCHP was not taken as a major measure between 2013 and 2016 by either the central government or local governments. Most regions mainly concentrated on promoting clean briquette and matched stoves to substitute bulk coal (Wei et al., 2016). Yet, the clean briquette substitution strategy achieved disappointing progress, due to poor properties of clean briquette (e.g., high price, difficult to burn), difficulties in controlling bulk coal market, and weak incentives from local governments (Wei et al., 2016; Focus Interview, 2017). In a sense, local governments were waiting for advanced technological models to accomplish the tasks of bulk coal reduction. In the middle of 2016, CAE, the top tier academic institute of engineering in China, conducted a midterm evaluation of the progress and effectiveness of the 2013 Action Plan. Among various findings, the evaluation report explicitly listed rural civil bulk coal for heating as one of the most prominent factors for severe winter air pollution, which had not been systematically attended to by that time (CAE, 2016). As a result, the report advocated coal-to-electricity and coal-to-gas transition of residential heating as major measures to reduce consumption of civil bulk coal in BTH rural region, in order to achieve the target of the 2013 Action Plan by 2017 (CAE, 2016). The CAE report played a critical role in the formulation of CCHP. 
As, Lei Yu, a high-ranking official from MEE, stated, "The midterm evaluation report helped the central government make the mind. The government provides sufficient administrative resources to promote coal-to-gas and coal-to-electricity, such as financial subsidy, top-down task assignment, among others. It is not just 'encourage' anymore (as before), which made you (local governments) act slowly". (Huang et al., 2017).

What's more, a few rounds of heavy air pollution swept Beijing and surrounding areas in the winter of 2016, which further accelerated the policy formulation of CCHP (Huang et al., 2017). Most importantly, CCHP gained strong and explicit political support at this time. In December, 2016, President Xi Jinping explicitly spoke for CCHP in a high-end meeting,

"Promoting clean heating in northern China matters significantly, which is about to make the people live a warm winter, about the reduction of smog, and is an important section of the revolution of energy production and consumption, as well as the revolution of rural life style. It should be promoted according to the principle of 'enterprises play the major part, government promotes it, and residents can afford it'. Choose gas or electricity based on local conditions, and try best to improve the proportion of clean heating." (Xinhua Net, 2016)

Before long, Premier Li Keqiang listed CTG and CTE projects as a major administrative task in his annual government report in March, 2017. Hereto, driven by strong political and administrative mobilization, scientific justification and external driver from climatic conditions, the "windows of opportunity" for CCHP, particularly CTG and CTE projects, opened. In consequence, from the beginning of 2017, an array of policies from central administrations were intensively issued to enforce CCHP. Aggressive tasks were assigned to local governments to accomplish before the end of October in 2017.

It should be noted that suspicion of the proposed technological models was not absent in the scientific realm, even within CAE itself. Despite scientists in general approve that civil bulk coal is a major contributor to severe air pollution in northern China, they hold different viewpoints regarding technological roadmaps, particularly for technological models in the dispersedly distributed countryside. Doubts were raised in two aspects, mainly regarding the CTG model (Zhang, 2019a; Tao, 2019). Firstly, natural gas should not be taken as clean energy, since its combustion also generates $\mathrm{NO}_{\mathrm{x}}$-a major air pollutant. Secondly, the coal-dominated natural energy endowment of China makes radical coal replacement unrealistic, and heavy reliance on import of natural gas generates high risks of energy security. A more practical approach hence is to improve building insulation and utilize clean briquette (together with advanced stoves) to replace bulk coal in rural areas (Kou, 2017; Tao, 2019). However, these scientific suspicion was marginalized in the policy formulation of CCHP.

Another critical issue is that the temporal gap between policy output and outcome is exceptionally short. Premier Li Keqiang announced the tasks in March 2017, leaving only approximately six months for local governments to put into practice. The short timeframe pressured local governments to accomplish their tasks as quickly as they could. They had few choices but to follow the two models proposed by the central government. Moreover, most local governments at the beginning preferred CTG model among the two due to its attributes of technological maturity, lower costs, and higher feasibility of rapid promotion (Liu et al., 2019). In this process, the public, more specifically the energy enterprises and the recipient communities, were largely excluded in the decisionmaking of technological model selection.

\section{Setting Policy Objectives}

Policy objective setting is an important part in policy formulation. Low-carbon energy policies are frequently situated in a difficult position to satisfy multiple (often conflicting) objectives, including objectives regarding economics (accessibility and affordability), politics (energy security) and environment (emission reduction). In practice, each of these objectives or concerns tends to drive energy policies toward its own direction (Heffron et al., 2018). Energy policies that manage to balance these multiple objectives serve the best option in policy-making (Heffron et al., 2018). Poorly aligned policy objectives frequently lead to policy failure in public policies in general (Wu et al., 2010), and in sustainable transitions in particular (Howes et al., 2017). Although not explicitly stated in the policy documents, CCHP was propagated as a national project with two goals (i.e., environmental and developmental): 1. to ameliorate air pollution in northern China, and 2. to improve the living standards of rural people through accessing clean and affordable energies. However, CCHP was originally nested in the air pollution mitigation framework, and its effectiveness is measured only by three major environmental indicators, i.e., the decreasing quantity of bulk coal, the decline degree of key pollutant density (i.e., $\mathrm{PM}_{2.5}$ and $\mathrm{SO}_{2}$ ), and the number of reduced heavily polluted days (Wang et al., 2019a). Indicators of well-being and life quality of the recipients were explicitly absent in the policy texts. Namely, the evaluation standards mainly point to the scale of civil bulk coal reduction estimated by the quantity of households that participate in CCHP. The partiality of policy goal setting in this stage induced local governments to concentrate on those environmental indicators, which generated severe consequences as shown in subsequent policy processes.

\section{Conducting Policy Experimentation}

Policy experimentation is a distinctive feature of Chinese policy process (Heilmann, 2008; Lo and Broto, 2019). In policy experimentation, pilot projects are initiated to test and evaluate the effectiveness of different policy methods and examine the reactions from the society, before formal policy formulation and implementation (Heilmann, 2008). In light of that, policy experimentation is a valuable strategy of selecting appropriate policy instruments and achieving effective policy outcomes in the context of China's vast socio-economic heterogeneity (Heilmann, 2008). The experimentation model was also adopted in the policy process of CCHP. In 2017, the central government selected 12 cities to conduct cleaning heating pilot projects, and the number was enlarged to 43 in 2019. However, it falls short in two aspects. Firstly, common policy 


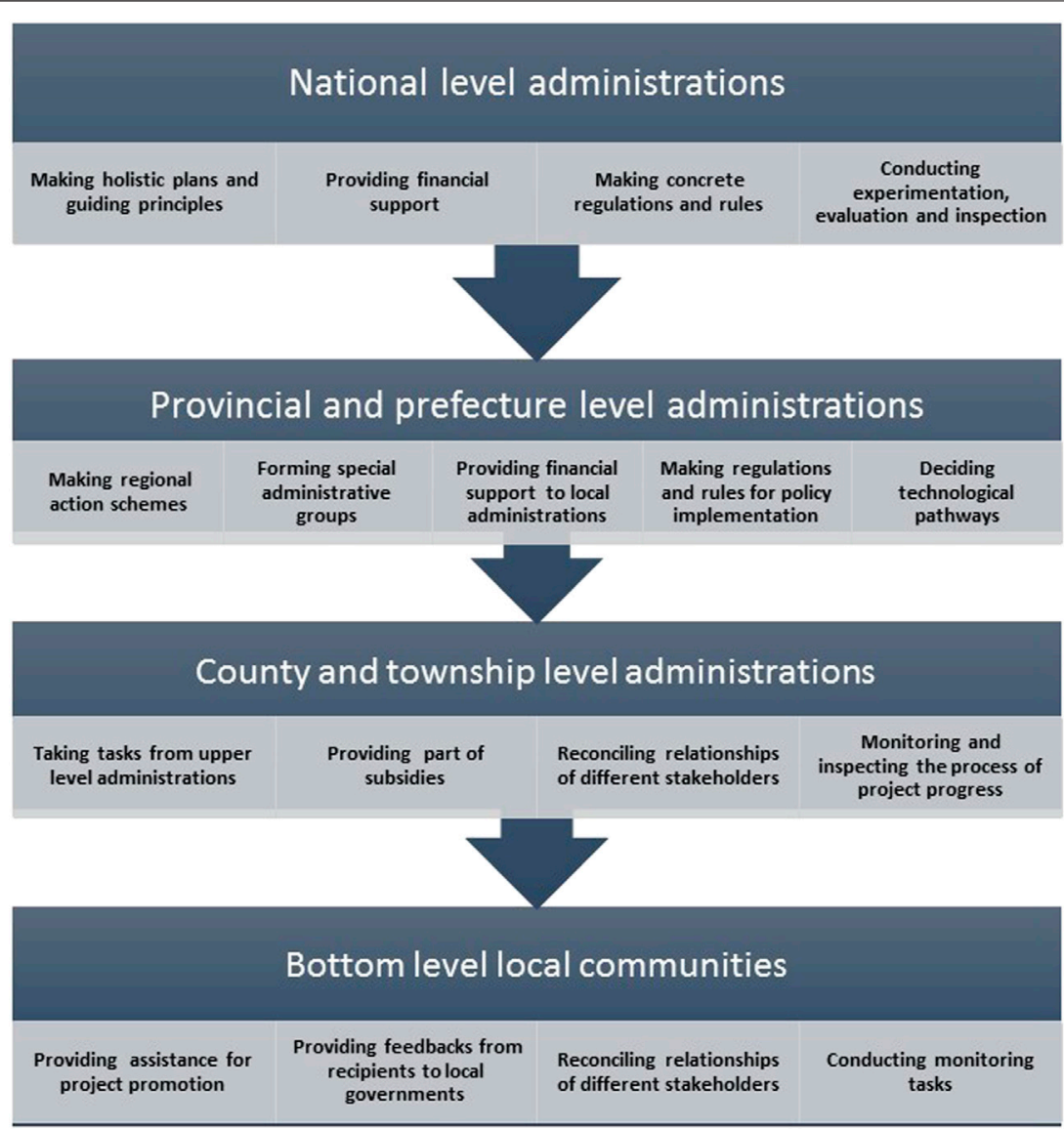

FIGURE 5 | The top-down policy implementation mode of CCHP.

experimentation commences before formal policy formulation and rollout, in order to learn the real effectiveness of different policy designs. In CCHP, however, pilot programs and national-scale promotion were conducted simultaneously, which resulted in ignorance of many social problems generated by CCHP in subsequent implementation. Secondly, the technological roadmaps for pilot cities were basically confined to the two main models proposed by the central government, although the policy texts ostensibly encouraged the pilot cities to explore multiple technological models. Consequently, policy experimentation of CCHP failed to provide real-world feedbacks of different technological models; instead, most pilot cities promoted CCHP blindly and aggressively in order to fulfill administrative tasks and grab financial support.

This section shows that the formulation of CCHP has been mainly driven by political and administrative dynamics, and largely overlooked the societal aspects. The selection of technological models and the policy experimentation were poorly coordinated, which challenges the frequently heard comments that the policy design of CCHP is correct, and problems lie with the implementation at the local level ( $\mathrm{Li}$ and Feng, 2017; Chu, 2018; Li, 2018).

\section{Policy Implementation}

Policy implementation represents a complicated process of putting formulated policies into practice, and involves multiple aspects, such as participant groups, organizational mechanisms, and selection of policy instruments, among others (Stewart et al., 2007). This section focuses on two aspects of the implementation of CCHP: 1. the major approach in terms of organizational mechanisms; and 2. the selection of policy instruments.

\section{Top-Down Administrative Mechanisms}

The policy implementation of CCHP took an explicit top-down command-and-control approach by the administrative system (He et al., 2019; Qi and Xiao, 2019). First, the extensive promotion of CCHP was proposed, designed, and driven by the central government. Local governments in general were pushed to implement the policy tasks assigned by the central government. As mentioned above, it was the call from the central government that truly drove local governments to enforce this project. The enforcement pressure was vertically channeled from the central down to the county and township level administrations, as summarized by Figure 5. Pressure from every layer of administration would push their lower level 
TABLE 2 | Major policy instruments of CCHP as implied by the policy discourse.

\begin{tabular}{|c|c|c|}
\hline Category & Concrete instruments & Major content \\
\hline $\begin{array}{l}\text { Mandatory } \\
\text { instruments }\end{array}$ & $\begin{array}{l}\text { Political mobilization } \\
\text { Administrative organization } \\
\text { Regulations }\end{array}$ & $\begin{array}{l}\text { Take CCHP as a major political task } \\
\text { Form specific organizational mechanisms for CCHP at both national and local levels } \\
\text { Set mandatory and regulative action plans within administrative system } \\
\text { - Execute market regulation of civil bulk coal } \\
\text { Regulate gas and electricity price mechanisms } \\
\text { Establish environmental inspection institutions } \\
\text { Establish policy task-evaluation institutions }\end{array}$ \\
\hline Mixed instruments & $\begin{array}{l}\text { Subsidy } \\
\text { Contract } \\
\text { Financing } \\
\text { Information and exhortation }\end{array}$ & $\begin{array}{l}\text { Provide substantial subsidies from the central government to local governments, and from governments to } \\
\text { recipients } \\
\text { Select and subsidize pilot cities for conducting CCHP } \\
\text { Outsource the project to energy enterprises } \\
\text { Encourage banks to give loan to market entities related with CCHP } \\
\text { Support clean heating enterprises to conduct financing } \\
\text { Encourage state-owned central enterprises to participate in CCHP with supportive performance } \\
\text { assessment institutions } \\
\text { Provide information of different technologies to local governments and rural residents } \\
\text { Conduct publicity to rural residents about the advantages of clean heating }\end{array}$ \\
\hline Voluntary instruments & $\begin{array}{l}\text { Rural residents and } \\
\text { communities } \\
\text { Private enterprises }\end{array}$ & $\begin{array}{l}\text { Endow rural residents with the right of voluntary option } \\
\text { Encourage local community to choose viable projects based on local conditions } \\
\text { Encourage people to report malfeasance of officials via specific channels } \\
\text { Invite social (private) investments to participate in clean heating }\end{array}$ \\
\hline
\end{tabular}

Source: Author's compilation from CCHP policy documents.

administration to add more tasks. In the vertical administrative chain, county level and beneath administrations had little autonomy in the decision-making but simply served as policy executors in order to fulfill the tasks set by upper level administrations. Furthermore, the central government has established stringent inspection institutions since 2013, wherein the responsibility of air quality amelioration was transferred from environmental administrations to local governments, or more specially, to the principal leaders of local governments (Clean Air Asia, 2019). Hence, local leaders hold accountability for the air quality indicators, through mechanisms such as seasonal report, semiannual inquiry, annual accountability, and reinforced inspection, among others. According to the inspection rules, failing or even being slow to meet the targets would negatively impact the evaluation of those local leaders, so that immense pressure was created and transmitted layer by layer down to the local administrations (Clean Air Asia, 2019).

\section{Policy Instruments Dominated by Mandatory Ones}

Policy instruments are an integral part of policy implementation, serving as concrete methods in policy execution. Due to extreme complexity, policy instruments have been categorized diversely by scholars based on different criteria. This article adopts the widely used classification according to mandatory degree, which groups policy instruments into three major types: mandatory, mixed and voluntary instruments (Doren and Phidd, 1992; Howlett and Remash, 1995). A combination of multiple instruments were supposed to be taken to enforce CCHP, as shown by the policy design from the central government (see Table 2). The mandatory instruments manifest in three aspects.
First, political mobilization is a decisive instrument adopted by all levels of administrations to enforce CCHP. In the policy discourse, the political significance of CCHP was explicitly and repeatedly stressed, whereby this project was constructed as a grand political task. Policy documents, work reports, and social media commentaries constantly quoted President Xi's speech on clean heating to accentuate the political significance of CCHP. Second, as discussed above, the central government designed specific organizational mechanisms to implement CCHP. A range of ministry-level administrations, such as NDRC, MEE, NAE, MHURD and MF, among others, were organized into an ad hoc leading group, with clear function divisions and coordinated institutions. Correspondingly, local governments were required to establish specific organizational entities and mechanisms to promote CCHP (Song et al., 2019). Figure 6 shows a typical organizational approach that local governments adopt. To be clear, Figure 6 takes Beijing City as an exemplar, and various policy documents and governmental websites show that other provinces followed a similar approach. This highly centralized administrative mechanism can efficiently mobilize various resources to implement the project. Third, various administrative regulations were issued to enforce CCHP, including administrative tasks, rules and arrangements of evaluation and inspection, and energy price regulations, among others.

For mixed policy instruments, four aspects can be observed in CCHP. The first, also the foremost, is substantial subsidies from various levels of administrations to project recipients. The amount of ultimate subsides is contingent on the financial ability of local governments. In general, Beijing and Tianjin, the two wealthiest municipalities in northern China, provide 


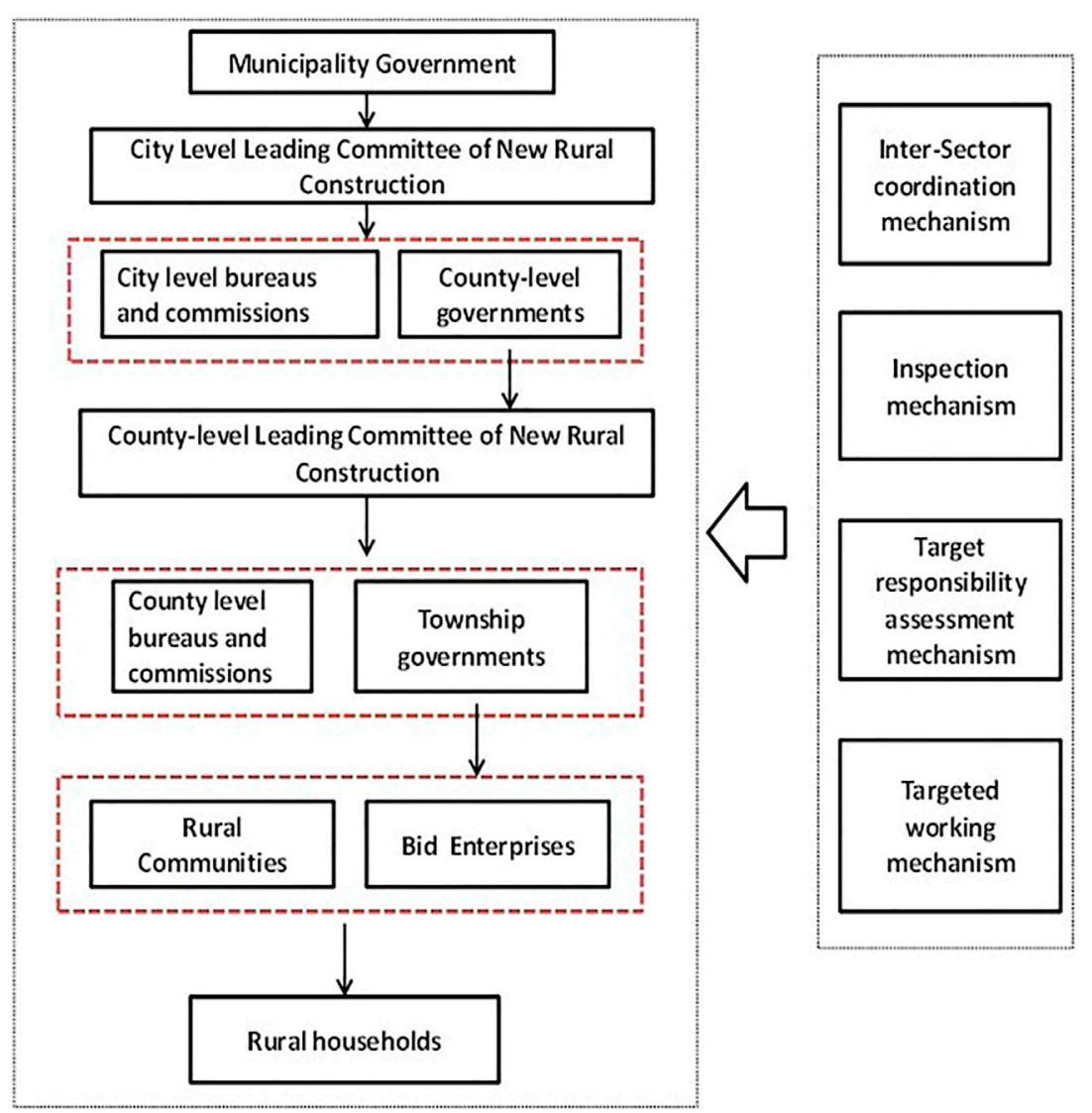

FIGURE 6 | The organizational mechanism for CCHP of Beijing City. Data source: adapted from CCHP related policy documents of Beijing (Beijing, 2018).

the most generous subsidies for their CCHP recipients. Less wealthy regions, such as Hebei and Shanxi Provinces, often provide a lower level of subsidies. Second, contracting out the project to qualified energy enterprises through open bidding is the main tool of executing CCHP. Third, local governments are encouraged to help enterprises to acquire financing in CCHP. State-owned central energy enterprises are encouraged to participate in clean heating. Fourth, apart from economic incentives, information provision and exhortation are also important instruments. Concrete technological roadmaps and details are provided to local governments, participant enterprises and recipients. Publicity is taken as a necessary method to pursue social acceptance from rural recipients.

Voluntary instruments are not explicitly emphasized, but all the policy documents highlight that the implementation of CCHP should respect the willingness of recipients, take local concrete conditions into account, and most importantly, ensure the affordability as the core principle of promotion. Besides, private investments are encouraged to participate in CCHP.

In practice, the instrument pluralism by design, however, was translated into a monism dominated by the mandatory ones. The proposed policy model featured by coordinated cooperation among stakeholders (market-government-recipient) was translated into a "government dominance" model, featured by strong irrationality, short-termism, inflexibility and blindness.
Local governments took stern measures to remove the obstacles in CCHP promotion. For example, many local governments frequently adopted mandatory methods to shut down local bulk coal markets. Rural recipients were left with very limited choices, and even forced to accept CCHP (Wang et al., 2018; Hu, 2020). It was reported repeatedly that local residents were forced to remove stoves and take gas or electricity (MEE, 2018). Preliminary planning and investigation on the availability of energy supply, local natural endowments, and local economy levels were neglected in the implementation process, which directly caused the supply shortage of natural gas in 2017. To summarize, the implementation of CCHP took a sweeping campaign-style manner, featured by rapid and extraordinary mobilization of political and administrative resources, and non-deliberative enforcement.

\section{Policy Evaluation}

Policy evaluation is a crucial section of policy process, during which specific evaluation bodies assess the outcome, efficacy and process of specific policies according to specific standards and procedures (Wu et al., 2010). Policy evaluation provides feedbacks for policymakers and implementers to examine policy effectiveness and make subsequent adjustments. The evaluation of CCHP has been provided by multiple bodies through both formal and informal channels. The first, which 
TABLE 3 | Evaluations of CCHP on environmental and socio-economic aspects by academics.

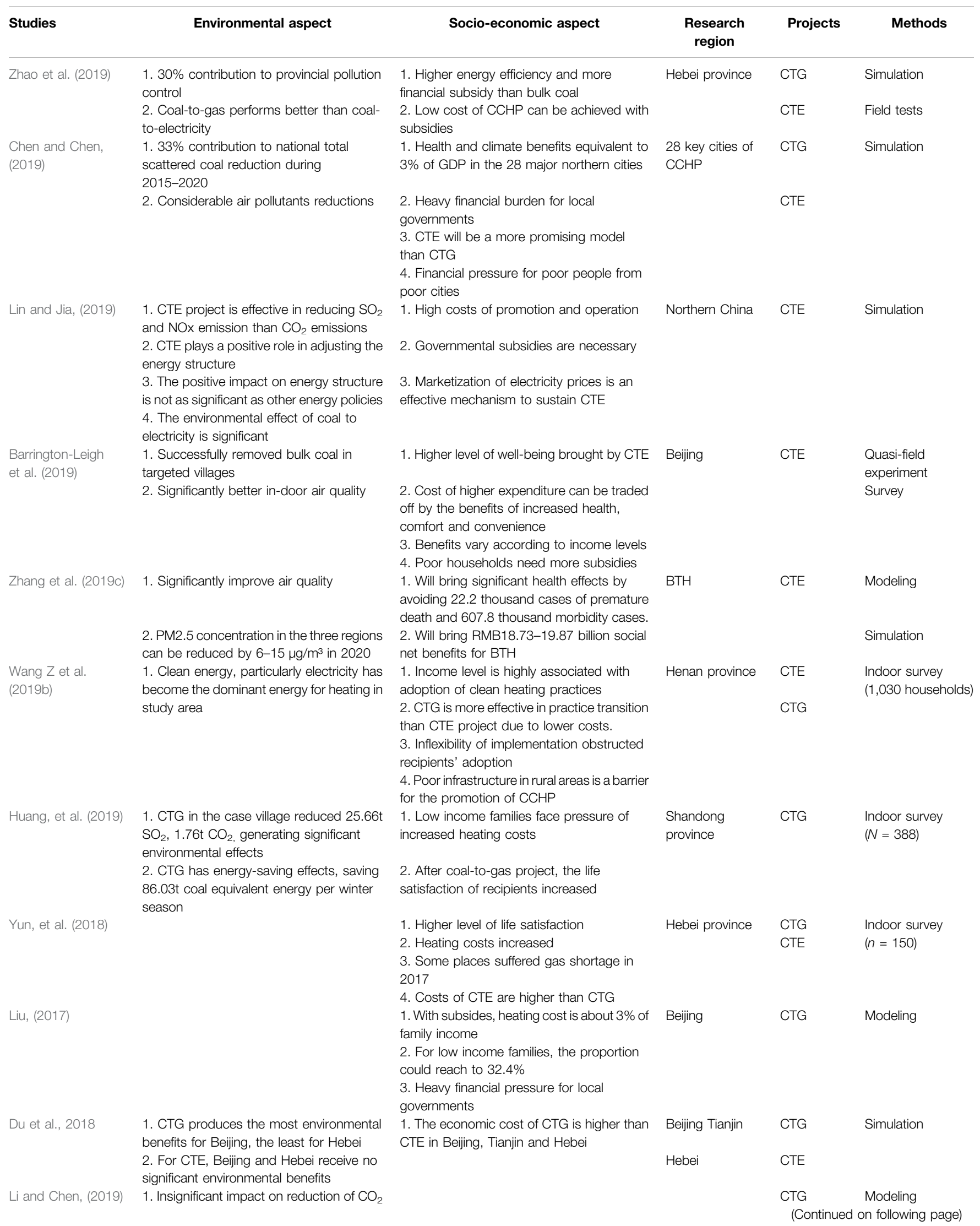


TABLE 3 | (Continued) Evaluations of CCHP on environmental and socio-economic aspects by academics.

\begin{tabular}{|c|c|c|c|c|c|}
\hline Studies & Environmental aspect & Socio-economic aspect & $\begin{array}{l}\text { Research } \\
\text { region }\end{array}$ & Projects & Methods \\
\hline & $\begin{array}{l}\text { 2. Insignificant impact on energy } \\
\text { consumption per unit of GDP }\end{array}$ & $\begin{array}{l}\text { 1. CTG and CTE have not significantly } \\
\text { increased the quantity of gas provision and } \\
\text { electricity consumption }\end{array}$ & $\begin{array}{l}41 \text { cities from } \\
\text { northern China }\end{array}$ & CTE & \\
\hline \multirow[t]{3}{*}{ Wu, et al. (2018) } & & $\begin{array}{l}\text { 1. } 24-65 \% \text { of rural recipients did not use the } \\
\text { heating devices; the electricity consumption } \\
\text { quantity of } 11-26 \% \text { of recipients was zero }\end{array}$ & $\begin{array}{l}\text { Beijing, Tianjing, } \\
\text { Hebei and Henan }\end{array}$ & CTE & Case study \\
\hline & & $\begin{array}{l}\text { 2. Subsidies took } 30-70 \% \text { of heating } \\
\text { electricity costs }\end{array}$ & & & $\begin{array}{l}\text { Secondary dataset } \\
\text { from grid } \\
\text { enterprises }\end{array}$ \\
\hline & & $\begin{array}{l}\text { 3. Low profitability of rural coal-to-electricity } \\
\text { projects could not attract private capital } \\
\text { investment }\end{array}$ & & & \\
\hline Yan et al. (2019) & $\begin{array}{l}\text { 1. Significantly reduce PM2.5 in Beijing, } \\
\text { Tianjin and Hebei } \\
\text { 2. Beijing and Tianjin achieve much more } \\
\text { environmental effects than Hebei. }\end{array}$ & $\begin{array}{l}\text { 1. Significant health benefits for Beijing, } \\
\text { Tianjin and Hebei } \\
\text { 2. Beijing will achieve the largest health } \\
\text { benefits, with Hebei second, and Tianjin third }\end{array}$ & $\begin{array}{l}\text { Beijing, Tianjin } \\
\text { and Hebei }\end{array}$ & CTE & $\begin{array}{l}\text { Simulation } \\
\text { modeling }\end{array}$ \\
\hline \multirow[t]{2}{*}{ Song, et al. (2019) } & $\begin{array}{l}\text { 1. The PM2.5 of } 12 \text { pilot cities in } 2017 \text { has } \\
\text { declined about } 30 \% \text { compared to } 2016 \text {, } \\
\text { some cities more than } 40 \%\end{array}$ & 1. Some cities face heavy financial pressure & $\begin{array}{l}12 \text { pilot cities } \\
\text { from northern } \\
\text { China }\end{array}$ & CTE & Fieldwork \\
\hline & $\begin{array}{l}\text { 2. All } 12 \text { pilot cities accomplished the } \\
\text { PM2.5 reduction tasks set by MEE }\end{array}$ & $\begin{array}{l}\text { 2. Gas prices rose up due to increased gas } \\
\text { demand } \\
\text { 3. Poor rural grid infrastructure restrained the } \\
\text { promotion of CTE } \\
\text { 4. Expenditure of CTG recipients increased } \\
\text { RMB874 after subsidy, that of CTE RMB1333. } \\
\text { 5. Majority of rural recipients fell into energy } \\
\text { poverty after CCHP }\end{array}$ & & CTG & Secondary data \\
\hline \multirow[t]{3}{*}{ Meng et al. (2019) } & $\begin{array}{l}\text { 1. More than } 60 \% \text { of households will remove } \\
\text { solid fuels by } 2021 \text { in northern China }\end{array}$ & 1. Significantly improve indoor air quality & $\begin{array}{l}28 \text { key cities in } \\
\text { northern China }\end{array}$ & CTE & $\begin{array}{l}\text { Survey-based } \\
\text { modeling }\end{array}$ \\
\hline & $\begin{array}{l}\text { 2. CCHP will significantly reduce PM2.5 } \\
\text { intensity }\end{array}$ & 2. Rural women benefit more than rural men & & CTG & \\
\hline & & $\begin{array}{l}\text { 3. Exposure reduction comes more from } \\
\text { improved indoor air quality than ambient air } \\
\text { quality } \\
\text { 4. Financial burden as a major constraint }\end{array}$ & & & \\
\hline \multirow[t]{3}{*}{ Xie, et al. (2019) } & $\begin{array}{l}\text { 1. Bulk coal was significantly reduced after } \\
\text { CCHP }\end{array}$ & $\begin{array}{l}\text { 1. CTE and CTG significantly increased } \\
\text { heating costs }\end{array}$ & Beijing & CTE & $\begin{array}{l}\text { Indoor survey }(N= \\
\text { 3949) }\end{array}$ \\
\hline & $\begin{array}{l}\text { 2. Environmental benefits are greater than } \\
\text { economic cost }\end{array}$ & $\begin{array}{l}\text { 2. CTE and CTG improved subjective } \\
\text { satisfaction of rural recipients }\end{array}$ & & CTG & \\
\hline & & $\begin{array}{l}\text { 3. Mandatory promotion harmed well-being } \\
\text { of recipients } \\
\text { 4. Universal subsidy led to energy inequality } \\
\text { for heating }\end{array}$ & & CTCC & \\
\hline Xu and Ge, (2020) & & $\begin{array}{l}\text { 1. Overall satisfaction of residents regarding } \\
\text { CTG is medium } \\
\text { 2. Residents are satisfied with the heating level; } \\
\text { but not satisfied with the subsidy amount }\end{array}$ & Hebei & CTE & $\begin{array}{l}\text { Indoor survey } \\
(N=908)\end{array}$ \\
\hline Wang et al. (2020) & $\begin{array}{l}\text { 1. CTG and CTE contributed to } 60 \% \text { of } \\
\text { total PM } 2.5 \text { reduction in winter } 2017 \text { in } \\
\text { northern China } \\
\text { 2. The gas shortage triggered by blind } \\
\text { promotion of CTG in } 2017 \text { indirectly } \\
\text { contributed } 15 \% \text { upsurge of PM } 2.5 \text { in } \\
\text { Southern China }\end{array}$ & & $\begin{array}{l}2+26 \text { cities in } \\
\text { northern China }\end{array}$ & $\begin{array}{l}\text { CTG } \\
\text { and CTE }\end{array}$ & Simulation \\
\hline Zhang et al. (2020) & $\begin{array}{l}\text { 1. CCHP can effectively reduce pollutant } \\
\text { emissions in northern China }\end{array}$ & & $\begin{array}{l}35 \text { pilot cities in } \\
\text { northern China }\end{array}$ & $\begin{array}{l}\text { CTG, } \\
\text { CTEetc. }\end{array}$ & $\begin{array}{l}\text { Daily monitored } \\
\text { panel data }\end{array}$ \\
\hline Yan et al. (2020) & & $\begin{array}{l}\text { 1. The CTG project nearly doubled the } \\
\text { heating expenditure of rural recipients }\end{array}$ & $\begin{array}{l}\text { One county in } \\
\text { Shanxi province }\end{array}$ & CTG & Survey $(n=374)$ \\
\hline
\end{tabular}

heating expenditure of rural recipients

2. Contemporary compensation standards are insufficient to cover the increased cost brought by the CTG project

3. The low income level of rural households is the main barrier to clean energy transition
Shanxi province
Secondary dataset from grid enterprises

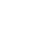


TABLE 3 | (Continued) Evaluations of CCHP on environmental and socio-economic aspects by academics.

\begin{tabular}{|c|c|c|c|c|c|}
\hline Studies & Environmental aspect & Socio-economic aspect & $\begin{array}{l}\text { Research } \\
\text { region }\end{array}$ & Projects & Methods \\
\hline Wu, et al. (2020) & $\begin{array}{l}\text { 1. Coal in CTE targeted area was effectively } \\
\text { reduced. } \\
\text { 2. Indoor and outdoor air quality were } \\
\text { improved due to the CTE implementation }\end{array}$ & $\begin{array}{l}\text { 1. Households involved in CTE received poor } \\
\text { heating experience } \\
\text { 2. High heating costs brought by CTE are } \\
\text { unbearable for rural poor households. } \\
\text { 3. Clean coal program is more viable for rural } \\
\text { households }\end{array}$ & $\begin{array}{l}\text { Beijing rural } \\
\text { villages }\end{array}$ & $\begin{array}{l}\text { CTE and } \\
\text { clean coal }\end{array}$ & Survey $(N=3949)$ \\
\hline Gong et al. (2020) & & $\begin{array}{l}\text { 1. Majority of rural households are willing to } \\
\text { pay clean heating less than RMB } 1000 \\
\text { 2. Financial support from government is } \\
\text { critical to the success of clean heating } \\
\text { project }\end{array}$ & $\begin{array}{l}\text { Hebi city, Henan } \\
\text { province }\end{array}$ & CTE & Survey $(N=324)$ \\
\hline
\end{tabular}

is informal but arguably the most influential and consequential, was the 2017 winter "gas shortage" crisis exposed by social media. Due to the aggressive promotion without considering gas provision, in the heating season of 2017, the supply of natural gas was in significant shortage across northern China (Huang et al., 2017; Shu and Shen, 2018). It was estimated that the national demand of gas increased by 33 billion $\mathrm{m}^{3}$ in 2017 , with a growth of $17 \%$, which was partly attributed by CCHP (Chen and Zhu, 2018). The increased gas demand for heating in Hebei Province, where 2.31 million rural residents participated in CTG project in 2017, reached 2.5 billion $\mathrm{m}^{3}$, and $25 \%$ of the demanded gas was in shortage (Chen and Zhu, 2018). An official report from MEE revealed that 426 thousand families from 1,208 villages or communities faced insufficient gas supply in the winter of 2017 (Du, 2017). The majority of these impacted groups were in low-level or even "zero" heating status (Zhu, 2017). This phenomenon was exposed by social media and quickly became a heated focusing event. Ministry-level administrations made quick responses to address the social crisis, including suspending the rollout of CTG and reconciling gas provision to satisfy the demand of civil heating. Apart from the gas shortage event, problems of poor affordability, delay of subsidies, public security concerns were also widely reported by social media (Zhou et al., 2018).

Another source of policy feedback comes from the administrative system itself. One featured action was the middle-term evaluation of CCHP pilot cities conducted by four ministry-level administrations in 2019. The report has not been formally published as yet, so that we can only learn from an NEA official who revealed a few brief conclusions on an international conference (Zhang, 2019b). First of all, the environmental goals of CCHP have been well accomplished. Also, clean heating markets and industries have achieved significant developments driven by the extensive promotion of CCHP. Moreover, residents are generally satisfied with the environmental and health effects brought by CCHP. Meanwhile, a multiplicity of problems are identified in evaluation, including the inflexibility of technological choices, poor affordability, and high rate of coal re-burning, among others. Besides the national-level evaluation, a few provincial-level governments, e.g., Hebei Province and Shanxi Province, conducted local investigation and evaluation of CCHP as well, with similar problems being found.

The third strand of feedback is from academia, as summarized by Table 3. Two major findings can be drawn from these studies. The first is that CCHP has been an effective tool in controlling civil bulk coal, and remarkably ameliorated air pollution and improved indoor air quality. The environmental effects generated by CCHP provide powerful justification for the continuous promotion of CCHP. The second finding is that CCHP caused many socio-economic problems, which may push the project into deep uncertainty. The two most prominent issues are poor affordability and heavy reliance on external subsidies. Therefore, how to build a sustainable pathway for CCHP is the most pressing issue for the policymakers.

Table 4 summarizes the multiple challenges that CCHP faces identified by the feedbacks from multiple sources. For an overall evaluation, besides the environmental effects, the challenges can be roughly grouped into two dimensions. The first concerns with the poor affordability of the technological models, revealing weak social legitimacy of CCHP. The unbearable expenditure of CTG and CTE is the foremost barrier for this mega project. The majority of CCHP recipients are rural residents, whose income level is generally low. Even rural residents from Beijing, the wealthiest region that CCHP targeted, also widely report difficulties in paying the surged heating costs (Xie et al., 2019). As estimated by researchers, the energy cost of CTG is approximately 3 times as high as that of bulk coal heating, and CTE 4 times of bulk coal (He and Li, 2018). Even with subsidies, the cost of new heating systems is still significantly higher than former bulk coal based heating systems ( $\mathrm{He}$ and $\mathrm{Li}$, 2018; Li, 2018). In average, the rural per capita net income of the CCHP key regions range from RMB 10,000 to 18,000 , and the willingness-to-pay for winter heating is less than RMB 2,000 ( $\mathrm{He}$ and $\mathrm{Li}, 2018$ ). According to a survey covering 975 participants from four provinces, $32 \%$ of CCHP rural recipients paid more than RMB 2,000 per heating season after deducting subsidies, out of whom 30\% paid between RMB 2,000-5,000 (He and Li, 2019).

For rural residents, the increased energy costs leads to heavy dependence on subsidies. Surveys show that the majority of rural 
TABLE $4 \mid$ The challenges of CCHP identified by governments, social media and intellectuals.

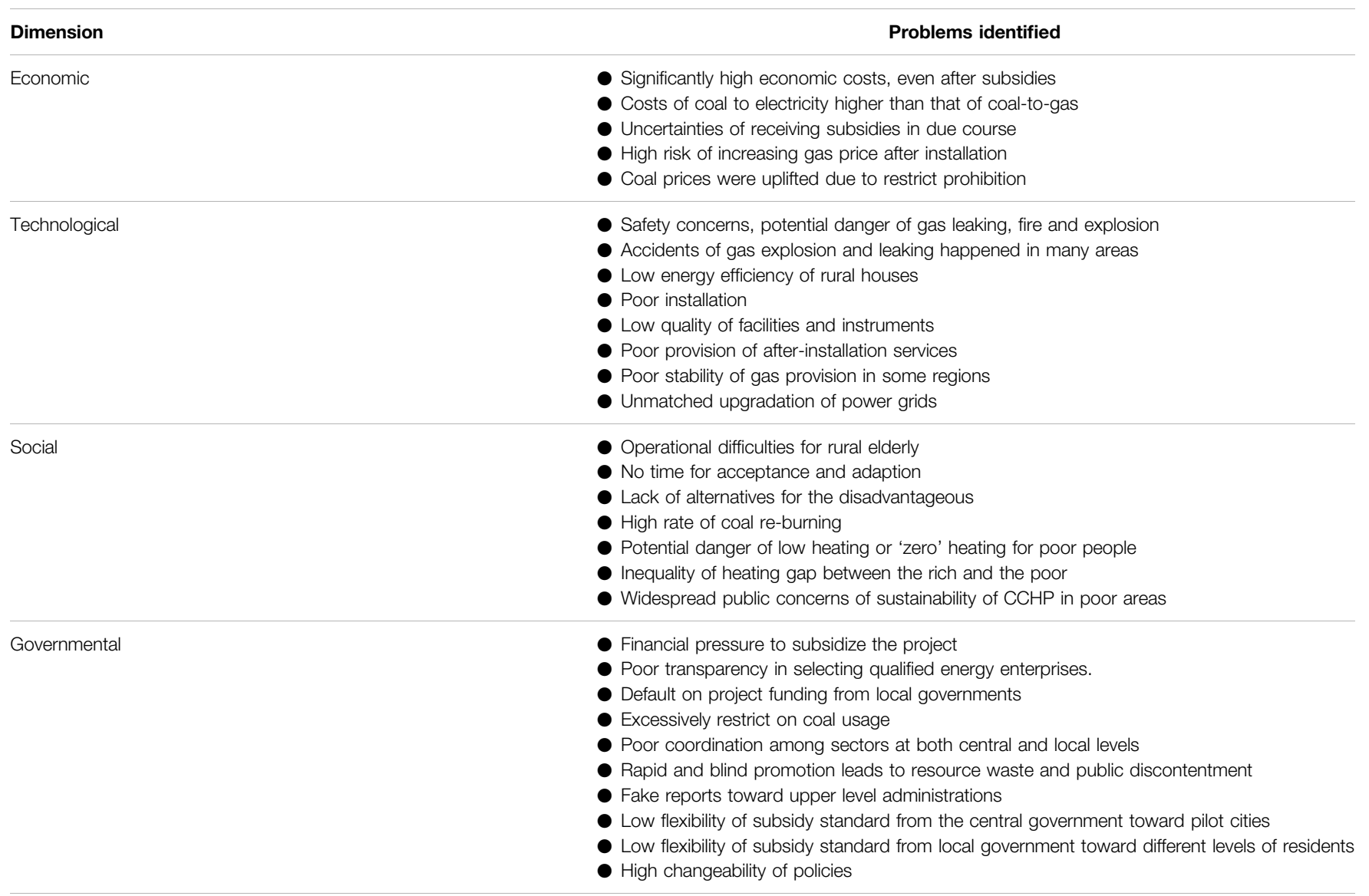

residents express that they will return to former heating practices if subsidies stop (Liu et al., 2019). He and Li (2019) also found from a survey $(n=1,635)$ that $43 \%$ of CCHP recipients said they would use coal again if subsidies stopped. Of the $43 \%$ participants, $99 \%$ are CTG and CTE recipients. Unsurprisingly, the poor affordability leads to high rate of returning to coal in practice. A survey reported by MEE in 2019 shows that in Baoding, a municipal city in Hebei province, over a third (36.1\%) of rural CCHP families returned to burn bulk coal (Zhang, 2019b). In consequence, the major governors of Baoding were criticized through circulating a notice by MEE because of poor monitoring work on bulk coal re-burning (Zhang, 2019b).

The second major challenge is associated with governance dilemma. Heavy subsidy placed heavy financial pressure on local governments. Particularly for the local governments from less wealthy regions, the financial pressure can be insurmountable ( $\mathrm{Li}$, 2018). More worrying is a consensus that CCHP subsidies will eventually reduce to zero in subsequent years. Retreat of subsidies in poor regions are very likely to create severe energy poverty in winter. In this sense, local governments face immense pressure of keeping the sustainability of CCHP, which could end with profound policy failure if no coordinated efforts are invested. In addition, policy flexibility has been a persistent challenge for
CCHP (Liu et al., 2019; He and Li, 2019). Although policy documents from national administrations reiterate the request of flexibility principle in implementing CCHP in the first place, local governments rarely followed in practice, as shown in the next subsection.

\section{Policy Adjustments}

In typical policy processes, policymakers make changes to address obstacles and improve policy effectiveness. Alongside the promotion of CCHP, a few adjustments can be identified driven by the feedbacks from multiple sources. First, the 2017 gas shortage crisis made the central government slow down the promotion pace of CCHP in 2018. A variety of national-level administrations issued policy notices to curb the "runaway" behavior of local governments, which was regarded as a "calm period" after the 2017 fad ( $\mathrm{He}$ and Li, 2019; National Energy Administration (NEA), 2018; Li et al., 2019). For example, Hebei Province conducted CCHP for 2.55 million rural households in 2017, and reduced to 1.8 million in 2018 ( $\mathrm{He}$ and $\mathrm{Li}, 2019$ ). Second, the central government explicitly expanded the range of technological models. In 2017 and before, technological choices were dominated by CTG and CTE, with very limited efforts taken to promote alternative models. From 2018, more technological choices were explicitly encouraged by the central government. 
The policy documents before 2018 stated the selection principle of technological roadmaps as "choosing (coal to) gas or (coal to) electricity according to local conditions", which was adjusted into "choosing gas, electricity, clean briquette, geotherm based on local conditions" after 2018. Clean briquette has been re-framed as a major model of heating energy transition since then. Renewable energy heating technologies such as biomass and solar heating have been particularly stressed by national-level administrations. In the middle of 2019, NEA issued an opinion soliciting draft and wished to resolve the problems occurred in the promotion of CTG and CTE projects. The draft explicitly proposed to balance different clean heating technological models, and give priority to biomass heating in rural regions. Third, national-level administrations tended to balance the two policy goals of CCHP, and urge local governments to follow the principle of "ensuring residents live a warm winter." But, the policy evaluation standards remain unchanged.

Despite the adjustments from the national-level administrations, local governments seemed reluctant to follow in practice. CTG and CTE have remained the major technological models in implementation; the promotion tasks have even increased consistently after 2018 (see Figure 1). A latest policy document reveals that in the year of 2020 , local governments planned to take over seven million rural households into CCHP, which is significantly higher than the five million task of 2019 (MEE, 2021). After 2017, mounting focusing events have kept exposing the coercive and one-size-fits-all implementation behavior of local implementers. Nonetheless, local governments still rush to increase coverage scale, with insufficient consideration regarding long-term project sustainability. Overall, the policy adjustments so far have shown marked limitations, and have not touched upon the major challenges of CCHP, leaving the mega project still in deep uncertainty.

\section{POLICY IMPLICATIONS: INSIGHTS FROM THE POLICY PROCESS PERSPECTIVE}

The above critical examination of five policy stages of CCHP has revealed key features of energy policy process in contemporary China, and identified manifold challenges that CCHP currently faces. Thorough readjustments beyond merely accentuating adjustments in the domain of local implementation are of necessity, if the well-intended project is to achieve ultimate success. Well-aligned policy process is a prerequisite for policy success (Wu et al., 2010). Based on the analysis of this article, a few policy implications illuminated by the policy process perspective can be drawn as follows.

\section{Aligning Policy Objectives and Policy Evaluation}

First of all, conflicting policy objectives have been identified as a significant reason for policy failure in sustainable transition (Kraft and Kamieniecki, 2012; Howes et al., 2017). Although environmental improvement and the well-being of impacted groups do not necessarily disaccord with each other, they render huge divergence in policy practices. Pursuing one often means sacrificing the other. For CCHP, the two objectives should be better aligned in future, not only in policy discourse, but also in concrete and operational policy instruments. For example, the institutions of evaluation and inspection regarding CCHP should go beyond the scale and speed of project promotion, but be geared to indicators associated with well-being, such as satisfaction of recipients, operational sustainability, etc. Besides, a balanced emphasis on well-being requires a concerted readjustment in policy evaluation. Contemporary policy evaluation of CCHP conducted by the administrative system is mainly guided by indicators associated with task accomplishment, energy provision and price stability, financial management and environmental targets, which primarily focuses on the technoeconomic dimension of the project and systematically overlooks the social well-being aspects. Future evaluation efforts should pursue more inclusive and balanced standards. For instance, indicators associated with residents' satisfaction regarding project installation, heating effect and post-installation services should be incorporated into future evaluation criteria. Moreover, the overall governance structure of CCHP has functioned to overemphasize environmental concerns, which should be adjusted in the future. In the rollout of CCHP heretofore, environmental administrations at multiple levels have played a central role in the policy initiation, implementation and evaluation, which inevitably caused prioritization of environmental goals over others. Regrettably, administrations that represent rural communities and residents, such as ministry and bureaus of agricultural and rural affairs, have not engaged in the rollout of CCHP since the beginning. Future adjustments should consider incorporating Ministry of Agricultural and Rural Affairs and its vertical branches into the governance structure of CCHP, which can generate a better balance between environmental concerns and farmers' welfare.

Lastly, from a pragmatic viewpoint, the pursuit of environmental goals should be based on properly designed and well-practiced compensation schemes, to avoid loss of social welfare caused by environmental projects. For CCHP, numerous studies have revealed the poor affordability of the dominant technological models, and also found poor effectiveness of current subsidy policies. Hence, in the future, subsidy policies and other measures should be reevaluated and readjusted, to fully realize their restorative potential for rural recipients' welfare. To a great degree, practicing restorative justice is crucial to achieve balance between environmental goals and social welfare improvement (Hu, 2020). .

\section{Making Policy Experimentation Better Inform Policy Formulation}

The policy experimentation in CCHP so far has offered little assistance in formulating well-fitted policy designs. In future, major revisions of policy experimentation are essential to release its potential in testing different technological models, identifying challenges, and preparing more practicable policies for subsequent extension in a broader scope. In so doing, the 
central government should take a flexible and tolerant approach to encouraging pilot cities to innovate and try out different technological models based on local backgrounds. Corresponding incentive arrangements should be designed to encourage local officials to innovate and practice suitable models. Moreover, the cooperation between R\&D and multilevel governments and enterprises should be further strengthened to offer local practitioners more selections of technological models.

\section{Forging Flexible Governance Mechanisms in Implementation}

Prior CCHP policy processes were featured by evident ossification, with limited flexibility in dealing with highly heterogeneous local conditions. Major reasons include excessive emphasis on political significance and harsh administrative inspection and evaluation. In future, no effort should be spared to explore flexible governing mechanisms. First, national-level administrations should be aware that energy transition is a long-term process filled with numerous relapses, frustrations, and even failures, and in most cases it cannot be completed in a compulsively confined time range (Sovacool, 2016). Therefore, top-level policymakers should be patient with the progress of energy transition. In policy design, toplevel administrations should incorporate the flexibility and toleration principles into concrete policy documents and practical strategies. Besides, substantial incentives in accordance with the principles should be provided to local governments who seek innovative models catering to local conditions. Second, as the major implementation body, county and township level administrations should be substantially empowered, enabling them to actively participate in the designing and executing CCHP based on concrete local conditions (Liu et al., 2019). Provincial and prefecture level administrations should restrain their roles more as supporters and monitors and less as commanders. A balanced relationship among the central, middle and street level administrations is of great necessity.

\section{Practicing Public Participation Throughout the Policy Process}

Effective public participation can significantly improve the social acceptance of energy policies. The policy processes of CCHP have witnessed insufficient public participation $(\mathrm{Hu}$, 2020). To a great degree, the challenges that CCHP currently face can be seen as an outcome of deficit public participation. Long-term operational sustainability entails meaningful participation from rural recipients, scientific experts (both natural and social scientists), and various social organizations, which should be integrated into various stages of the policy process. Specifically, meaningful participation from rural recipients can provide genuine feedbacks regarding viable technological roadmaps, effective policies, among others. Admittedly, formidable obstacles have long existed in realizing rural residents' genuine participation in policy processes in China. In most cases, rural residents serve as passive policy receivers, instead of active participants ( $\mathrm{Hu}$, 2020), and improving this remains a grave challenge. One possible approach to overcoming this challenge is to enhance local governance efficacy, especially village self-governance organization. In contemporary rural China, village selfgoverned organizations (Cun wei hui) serve as the most important institution that connects rural residents with upper-level administrations. Although they are established as a self-governed autonomous organization, the vast majority of these organizations, however, have become a de facto agent of the township-level governments, and therefore largely lost the mission of representing the will of rural residents. In the future, village self-governance organizations should be empowered by both institution reform and policy practice, which can potentially improve the participation of rural residents in policy process. For instance, technological models in CCHP are vital in determining the operational cost and the acceptability of local residents. Therefore, selection of local technological models should take a deliberative approach, value opinions of local village cadres and common residents, and avoid blunt top-down enforcement. Besides, informal voluntary social organizations in rural villages, such as elderly associations, women associations and various types of voluntary groups, can also be highly contributive to public participation. Fostering these social organizations and encouraging them to engage in policy design, implementation, monitoring and evaluation may significantly improve the policy outcome.

Another pathway can be giving more attention to direct opinions and appeals from rural residents from various channels, such as online appeal platforms. Local governments should exert timely responsiveness toward the direct appeals from rural residents, and this will form a virtuous circle of effective participation and good policy outcome. Ultimately, improving participation of rural residents entails systematic efforts, which goes beyond the governance system of CCHP, but core principles remain similar: on the one hand, to mobilize and empower local organizations, either formal or informal, and on the other, to improve the responsiveness of local administrations.

In addition, suggestions from scientists working in different fields (both natural and social sciences) can help form a holistic approach which embodies techno-economic, social, cultural and political justifications of CCHP. The design and evaluation of CCHP so far have been dominated by natural scientists, who stress heavily on the environmental and techno-economic aspects, while social scientists who are more qualified to provide advice on socio-political aspects are distinctly marginalized in the project. In the future, balanced expertise should be pursued in the process of policy consultation. Moreover, various social organizations may well serve as a link between mass society and governmental bodies, and should be encouraged to participate in the policy process of CCHP. Ultimately, how to build effective mechanisms to incorporate meaningful public participation is a great test for all level administrations in China. Failing to do so may lead this wellintended project to profound failure. 


\section{CONCLUSION}

Reduction of civil bulk coal is not only a pivotal strategy for contemporary China, but also an imperative for the whole world. The rapid promotion of CCHP epitomizes the forceful resolution of the Chinese government in addressing mounting environmental crises. Different from existing studies that mostly focus on specific parts of the policy process, the article examines this mega project from a policy process perspective. It shows that although with only a four-year intensive rollout, CCHP has generated significant environmental, social, economic and even political consequences. A comprehensive policy package has been efficiently formulated to promote clean heating energy transition in northern rural China. Marked environmental effects have been achieved, while formidable challenges have surfaced as well and driven the mega project into a deep dilemma. Attributing the contemporary dilemma to implementation failure at the local level offers little help in improving the effectiveness of CCHP. An examination of the policy process of CCHP provides a holistic understanding of this mega project. CCHP originated from a poorly articulated policy framework, and was propelled more by political momentum and less by socio-economic concerns. The policy design, which placed excessive emphasis on environmental imperative (driven by political concerns) and proposed reckless technological models, forced local practitioners to implement it in an ossified manner and neglect the socio-economic conditions of the recipients. The politics and administration oriented approach and severe deficit of public participation are salient features of the implementation process, and also major reasons for the contemporary dilemma. Although policy feedbacks to a great degree have informed the policy system of the multiple challenges, existent policy adjustments have

\section{REFERENCES}

An, P. (2017). Promoting Clean Heating Should Adopt 'flexible' Principle. Available at: http://www.xinhuanet.com/politics/2017-12/11/c_ 1122093890.htm (Assessed November 6, 2019).

Aunan, K., Hansen, M. H., and Wang, S. (2018). Introduction: Air Pollution in China. China Q. 234, 279-298. doi:10.1017/S0305741017001369

Barrington-Leigh, C., Baumgartner, J., Carter, E., Robinson, B. E., Tao, S., and Zhang, Y. (2019). An Evaluation of Air Quality, Home Heating and Well being under Beijing's Programme to Eliminate Household Coal Use, Nat. Energ., 4, 416-423. doi:10.1038/s41560-019-0386-2

Beijing (2018). Guidance Opinion on Winter Clean Heating Work in Rural Regions. Available at: http://www.beijing.gov.cn/zfxxgk/110019/zcxwj23/201805/18/ content_46bd64f74de94c6db8050431496a18ca.shtml (Assessed November 6, 2019).

Cao, J., and Hu, B. (2019). Research on the Interest Compensation Way of the Policy of "Coal to Gas and Coal to Electricity, Heat. Refrigeration (In Chinese), 5, 36-39.

Chen, H., and Chen, W. (2019). Potential Impact of Shifting Coal to Gas and Electricity for Building Sectors in 28 Major Northern Cities of China. Appl. Energ. 236, 1049-1061. doi:10.1016/j.apenergy.2018.12.051

Chen, Z., and Zhu, M. (2018). Heating Gas Demand Prediction of Hebei Residents after 'Coal-to-Gas' Project: Based on Big Sample Survey Data of Rural Family Energy Consumption. Chin. Price (in Chinese) 7, 64-66.

Chinese Academy of Engineering (CAE) (2016). Mid-term Evaluation Report of the Implementation of Air Pollution Prevention Action Plan. Published version: http://www.cae.cn/cae/html/main/col96/2016-07/05/20160705161134200910514_1. html (Assessed November 6, 2019). shown limited potential to tackle these obstacles. Policy recommendations inspired from the policy process perspective are discussed in detail, which mainly stress four aspects: realignment of complex policy goals and policy evaluation, policy experimentation, implementation flexibility and public participation.

Lastly, as a final summary, the policy process of CCHP illustrates that massive political, institutional and material resources do not guarantee a smooth and effective energy transition, no matter how ample the resources are. Energy transition is not just a technological change from coal to another energy type, but a systematic and complex process, involving multi-scale, multi-level, and multifaceted political and socio-economic dimensions. The multidimensionality of energy transition necessitates well aligned and integrated policy process, which requires researchers to look beyond individual policy stages and incorporate a holistic policy process framework in energy policy analysis (Kern and Rogge, 2018).

\section{AUTHOR CONTRIBUTIONS}

$\mathrm{ZH}$ : framing the article, collecting data and literatures, and writing the article.

\section{FUNDING}

This work is supported by the Fundamental Research Funds for the Central Universities (JB2018078).

Chu, B. (2018). Discarding "One-size-fits-all” Approach, and Demonstrating Governance Precision19th December. Beijing: People's Daily. Available at: http:// opinion.people.com.cn/n1/2018/1219/c1003-30474919.html (Assessed November 6, 2019).

Clean Air Asia (2019). China Air 2019: Air Pollution Prevention and Control Progress in Chinese Cities. Available at: http://allaboutair.cn/a/reports/2019/ 1126/565.html (Accessed December 3, 2019).

Doren, G. B., and Phidd, R. W. (1992). Canadian Public Policy: Ideas, Structure, Process. second edition. Scarborough: Nelson Canada.

Du, X., Feng, X., Wang, M., Zhao, M., and Liang, Q. (2018). Cost-benefit Analysis of Integrated Coal Treatment towards Clean Heating in Beijing-Tianjin-Hebei Region.Environ. Sustainable Dev. 43(6). 135-141. (in Chinese). doi:10.3969/ j.issn.1673-288X.2018.06.032

Du, X. (2017). Ministry of Ecology and Environment Conducted Special Inspection on winter Heating Guarantee for 2+26 Cities from Beijing-Tianjin-Hebei and Surrounding Region. 25th December, 2017 Available at: http://epaper.cenews. com.cn/html/1/2017-12/25/01B/2017122501B_pdf.pdf 25. (Accessed November 6, 2019).

Focus Interview (2017). Why Does Not Clean Briquette "Burn"? 22th May. Available at: http://tv.cntv.cn/video/C10326/5e01275a9bd549b98fc7162ec325035f? from=groupmessage\&isappinstalled $=1$ (Accessed November 6, 2019).

Gong, Y., Cai, B.-f., and Sun, Y. (2020). Perceived Fiscal Subsidy Predicts Rural Residential Acceptance of Clean Heating: Evidence from an Indoor-Survey in a Pilot City in China. Energy Policy 144, 111687. doi:10.1016/ j.enpol.2020.111687

Grossman, P. Z. (2015). Energy Shocks, Crises and the Policy Process: a Review of Theory and Application. Energy Policy 77, 56-69. doi:10.1016/ j.enpol.2014.11.031 
He, K., and Li, X. (2017). A Research Report of the Comprehensive Governance of China's Bulk Coal. Available at: http://coalcap.nrdc.cn/datum/info? $\mathrm{id}=68$ \& type $=1$ (Accessed November 6, 2019).

He, K., and Li, X. (2018). A Research Report of the Comprehensive Governance of China's Bulk Coal. Available at: http://coalcap.nrdc.cn/datum/info? $\mathrm{id}=68$ \&type $=1$ (Accessed November 6, 2019).

$\mathrm{He}, \mathrm{K}$., and Li, X. (2019). A Research Report of the Comprehensive Governance of China's Bulk Coal. Available at: http://coalcap.nrdc.cn/datum/info? id $=68$ \&type $=1$ (Assessed December 10, 2019).

$\mathrm{He}, \mathrm{K}$., and Li, X. (2020). A Research Report of the Comprehensive Governance of China's Bulk Coal. Available at: http://coalcap.nrdc.cn/datum/info? id=105\&type $=1$ (Accessed December 2, 2020).

He, W., Zhang, W., Wang, S., Chai, F., Li, H., Zhang, J., et al. (2019). Effects and Improvement Suggestions on Air Pollution Joint Prevention and Control Mechanism in Beijing-Tianjin-Hebei Region. Res. Environ. Sci. (In Chinese) 10, 1696-1703.

Heffron, R. J., McCauley, D., and de Rubens, G. Z. (2018). Balancing the Energy Trilemma through the Energy Justice Metric. Appl. Energ. 229, 1191-1201. doi:10.1016/j.apenergy.2018.08.073

Heilmann, S. (2008). Policy Experimentation in China's Economic Rise. St Comp. Int. Dev. 43, 1-26. doi:10.1007/s12116-007-9014-4

Howes, M., Wortley, L., Potts, R., Dedekorkut-Howes, A., Serrao-Neumann, S., Davidson, J., et al. (2017). Environmental Sustainability: A Case of Policy Implementation Failure?. sustainability 9 (165), 1-17. doi:10.3390/su9020165

Howlett, M., and Remash, M. (1995). Studying Public Policy: Policy Cycle and Policy Subsystem. New York: Oxford University Press.

$\mathrm{Hu}, \mathrm{Z}$. (2020). When Energy Justice Encounters Authoritarian Environmentalism: The Case of Clean Heating Energy Transitions in Rural China Energy Res. Soc. Sci., 70, 10177. doi:10.1016/j.erss.2020.101771

Huang, K., Zhou, C., Zhou, T., Li, R., and Wu, X. (2017). Drive for Clean Air Creates 'Chaos,' Leaves Thousands Shivering. December: Caixin. 11th. Available at: https://www.caixinglobal.com/2017-12-11/drive-for-clean-air-creates-chaosleaves-thousands-shivering-101183499.html?sourceEntityId=101182801 (Accessed November 6, 2019).

Huang, S., Chen, B., Luo, S., and Yuan, R. (2019). The Case Study and Analysis of 'Coal to Gas' Project in Rural Areas of Jinan-Based on the Research of Xianggaocun. City Gas (in Chinese) 533, 38-42. doi:10.3969/j.issn.16715152.2019.07.008

Jin, Y., Andersson, H., and Zhang, S. (2016). Air Pollution Control Policies in China: a Retrospective and Prospects. Ijerph 13, 1219. doi:10.3390/ ijerph13121219

Kern, F., and Rogge, K. S. (2018). Harnessing Theories of the Policy Process for Analysing the Politics of Sustainability Transitions: A Critical Survey. Environ. Innovation Societal Transitions 27, 102-117. doi:10.1016/j.eist.2017.11.001

Kou, J. (2017). Governing Bulk Coal Pollution, Thoughts Should Be Expanded. Beijing: People's Daily. (Accessed December 9, 2017).

Kraft, M. E., and Kamieniecki, S. (2012). The Oxford Handbook of U.S. Environmental Policy. Oxford: Oxford University Press. doi:10.1093/ oxfordhb/9780199744671.013.0031

Li, S., and Chen, M. (2019). The Impact of 'Coal-to-Gas' and 'Coal-to-Electricity' Policies on Green Development. Res. Financial Econ. Issues (in Chinese) 7, $49-56$.

Li, J., and Feng, X. (2017). Collectively Promote 'Coal to Gas' to Become a Moral Project for the People. Beijing: China Environment News 19th December. Available at: http://epaper.cenews.com.cn/html/2017-12/19/content_68320. htm (Accessed November 6, 2019).

Li, H., Fu, G., and Wu, S. (2019). Clean Heating: From a Priority of Clean Energy to a Balance with Well-Being. Beijing: China Energy News 4th, November Available at: http://paper.people.com.cn/zgnyb/html/2019-11/04/content_ 1954350.htm (Accessed November 8, 2019).

Li, G. (2018). Coal-to Gas and Coal-to-Electricity Contribute Significantly to the Governance of PM2.5. Available at: http://www.chinanews.com/gn/2018/03-19/ 8470974.shtml (Accessed November 6, 2019).

Lin, B., and Jia, Z. (2019). Economic, Energy and Environmental Impact of Coalto-Electricity Policy in China: A Dynamic Recursive CGE Study. Sci. Total Environ. 698, 134241. doi:10.1016/j.scitotenv.2019.134241

Liu, J., Mauzerall, D. L., Chen, Q., Zhang, Q., Song, Y., Peng, W., et al. (2016). Air Pollutant Emissions from Chinese Households: a Major and Underappreciated
Ambient Pollution Source. Proc. Natl. Acad. Sci. U.S.A. 113 (28), 7756-7761. doi:10.1073/pnas.1604537113

Liu, G., Xue, C., Ren, Y., Wan, W., Zhang, W., Xu, Y., et al. (2019). A Study of Winter Heating of Typical Northern Rural Regions of China. Available at: http:// www.allaboutair.cn/a/reports/2019/1031/564.html (Accessed December 3, 2019).

Liu, Y. (2017). Analysis of Affordability on Residents Heating with Coal to Gas: a Case Study in Urban and Rural of Beijing. Int. Pet. Econ. (in Chinese) 25 (6), $45-50$.

Lo, K., and Castán Broto, V. (2019). Co-benefits, Contradictions, and Multi-Level Governance of Low-Carbon Experimentation: Leveraging Solar Energy for Sustainable Development in China. Glob. Environ. Change 59, 101993. doi:10.1016/j.gloenvcha.2019.101993

Ma, Q., Cai, S., Wang, S., Zhao, B., Martin, R. V., Brauer, M., et al. (2017). Impacts of Coal Burning on Ambient PM2.5 Pollution in China. Atmos. Chem. Phys. 17, 4477-4491. doi:10.5194/acp-17-4477-2017

MEE (2018). Yingze District, Taiyuan City Controlled Coal by Coercion, and People Cannot Have a Warm Winter. Beijing: Available at: http://www.mee.gov.cn/ xxgk2018/xxgk/xxgk15/201811/t20181116_674178.html (Accessed November 6, 2019).

MEE (2019). Three Major Impacting Elements Are Found to Contribute to Air Pollution. Xinhua News Agency. 11th March. doi:10.1515/9789048544936 Available at: http://www.gov.cn/xinwen/2019-03/11/content_5372975.htm (Assessed November 6, 2019).

MEE (2020a). Ministry of Ecology and Environment Press Conference in December. Available at: http://www.mee.gov.cn/xxgk2018/xxgk/xxgk15/202012/ t20201229_815398.html (Accessed January 1, 2020).

MEE (2020b). Action Scheme of Comprehensive Governance of Autumn and Winter Air Pollution in BTH and Surrounding Area, and Fenwei River plain (2020-2021). Available at: http://www.mee.gov.cn/xxgk2018/xxgk/xxgk03/ 202011/t20201103_806152.html (Accessed January 1, 2021).

MEE (2021). China's Environmental Quality Report (2013-2019). Available at: http://www.mee.gov.cn/hjzl/sthjzk/zghjzkgb/ (Assessed January 20, 2021).

Meng, W., Zhong, Q., Chen, Y., Shen, H., Yun, X., Smith, K. R., et al. (2019). Energy and Air Pollution Benefits of Household Fuel Policies in Northern China. Proc. Natl. Acad. Sci. U.S.A. 116 (34), 16773-16780. doi:10.1073/ pnas. 1904182116

Ministry of Finance (MF). (2020). Notice on Distributing the Central Fund of Air Pollution Control in Advance. Available at: http://zyhj.mof.gov.cn/gjz/zjfp/ 201911/t20191115_3423099.htm (Assessed 6 November 2019).

National Energy Administration (NEA) (2018). National Energy Administration Notice on Conducting Well the 2018-2019 Winter Heating Work. Available at: http://www.gov.cn/xinwen/2018-12/15/content_5349109.htm (Accessed November 9, 2019).

Qi, J., and Xiao, J. (2019). The Interpretation of Administrative Law of the Calling off of the "Coal to Gas" Project. J. Huazhong Univ. Sci. Tech. (Social Sci. Edition) 33 (4), 82-92.

Sabatier, P. A., and Weible, C. M. (2014). Theories of the Policy Process. 3rd ed. Boulder, CO: Westview Press.

Shu, L., and Shen, X. (2018). How to Solve the Crisis of Gas Famine?. Caijing Mag. 518 (1). Available at: http://magazine.caijing.com.cn/20180108/4390458.shtml (Assessed November 6, 2019).

Song, L., He, J., Wu, J., Xu, Y., Cheng, L., Wang, Z., et al. (2019). Study on the Implementation Evaluation of Clean Heating Pilot City in Northern China. Environ. Prot. (in Chinese) 47 (9), 64-68.

Sovacool, B. K. (2016). How Long Will it Take? Conceptualizing the Temporal Dynamics of Energy Transitions. Energ. Res. Soc. Sci. 13, 202-215. doi:10.1016/ j.erss.2015.12.020

Stewart, J. J., Hedge, D. M., and Lester, J. P. (2007). Public Policy: An Evolutionary Approach. 3rd edition. Boston: Thomson Wadsworth.

Tao, G. (2019). Six Years of Tackling Smog. Available at: http://www.chplaza.com. cn/article-2867-1.html (Accessed November 6, 2019).

Thomas, S. (2016). The Hinkley Point Decision: an Analysis of the Policy Process. Energy Policy 96, 421-431. doi:10.1016/j.enpol.2016.06.021

Wang, Q., and Li, R. (2016). Journey to Burning Half of Global Coal: Trajectory and Drivers of China's Coal Use. Renew. Sustain. Energ. Rev. 58, 341-346. doi:10.1016/j.rser.2015.12.104

Wang, S., Su, H., Chen, C., Tao, W., Streets, D. G., Lu, Z., et al. (2020). Natural Gas Shortages during the "Coal-To-Gas" Transition in China Have Caused a Large 
Redistribution of Air Pollution in winter 2017. Proc. Natl. Acad. Sci. U.S.A. 117, 31018-31025. doi:10.1073/pnas.2007513117

Wang, Y., Zhang, S., and Hao, J. (2019a). Air Pollution Control in China: Progress, Challenges and Future Pathways. Res. Environ. Sci. (in Chinese) 32 (10), 1755-1762.

Wang, Z., Li, C., Cui, C., Liu, H., and Cai, B. (2019b). Cleaner Heating Choices in Northern Rural China: Household Factors and the Dual Substitution Policy. J. Environ. Manage. 249, 109433-109437. doi:10.1016/j.jenvman.2019.109433

Wang, S. (2008). Changing Models of China's Policy Agenda Setting. Mod. China 34 (1), 56-87. doi:10.1177/0097700407308169

Wang, Q. (2013). China's Citizens Must Act to Save Their Environment. Nature 497, 159. doi:10.1038/497159a

Wei, G., Cui, G., and Song, Y. (2016). Discussion on the Control of Coal Pollution in Beijing, Tianjin, Hebei. Environmental Protection (In Chinese) 6, 28-30.

Wu, X., Ramesh, M., Howlett, M., and Fritzen, S. (2010). The Public Policy Primer: Managing the Policy Process. London: Routledge.

Wu, L., Wu, D., Yan, X., Zhang, J., Zhao, B., and Zhang, Z. (2018). Performance Analysis of Rural "Coal to Electricity"in Beijing-Tianjin-Hebei. Power Demand Side Manage. (in Chinese) 20 (4), 36-41. doi:10.3969/j.issn.1009-1831.2018.04.008

Wu, S., Zheng, X., Khanna, N., and Feng, W. (2020). Fighting Coal - Effectiveness of Coal-Replacement Programs for Residential Heating in China: Empirical Findings from a Household Survey. Energ. Sustain. Dev. 55, 170-180. doi:10.1016/j.esd.2020.02.002

Xie, L., Chang, Y., and Lan, Y. (2019). The Effectiveness and Cost-Benefit Analysis of Clean Heating Program in Beijing. China Environ. Manage. (in Chinese) 3, 87-93.

Xie, X., Ai, H., and Deng, Z. (2020). Impacts of the Scattered Coal Consumption on PM2.5 Pollution in China. J. Clean. Prod. 245, 118922. doi:10.1016/ j.jclepro.2019.118922

Xinhua Net (2016). Meeting of the Leading Group for Financial and Economic Affairs: Adopting Clean Energies, Enhancing the Proportion of Clean Energies 21st, December. Available at: http://finance.china.com.cn/news/gnjj/20161221/ 4037342.shtml> (Accessed November 6, 2019).

Xu, S., and Ge, J. (2020). Sustainable Shifting from Coal to Gas in North China: an Analysis of Resident Satisfaction. Energy Policy 138, 111296. doi:10.1016/ j.enpol.2020.111296

Xu, P., Chen, Y., and Ye, X. (2013). Haze, Air Pollution, and Health in China. The Lancet 382, 2067. doi:10.1016/S0140-6736(13)62693-8

Yan, Z., Jin, L., Chen, X., Wang, H., Tang, Q., Wang, L., et al. (2019). Assessment of Air Pollutants Emission Reduction Potential and Health Benefits for 'Residential Heating Coal Changing to Electricity' in the Beijing-TianjinHebei Region. Res. Environ. Sci. (in Chinese) 32 (1), 95-103. doi:10.13198/ j.issn.1001-6929.2018.10.16

Yan, Y., Jiao, W., Wang, K., Huang, Y., Chen, J., and Han, Q. (2020). Coal-to-Gas Heating Compensation Standard and Willingness to Make Clean Energy Choices in Typical Rural Areas of Northern China. Energy Policy 145, 111698. doi:10.1016/j.enpol.2020.111698

Yang, H., and Li, P. (2019). Reform and Evolution of China's Policy Agenda. Henan Soc. Sci. (In Chinese) 27 (4), 10-15.

Yun, Y., Shao, Z., and Yao, D. (2018). Comparative Analysis on Operation Cost of Coal to Gas and Coal to Electricity in Hebei Province in Winter. Reg. Heat. (in Chinese) 4, 79-82.

Zhang, Z., Wang, W., Cheng, M., Liu, S., Xu, J., He, Y., et al. (2017). The Contribution of Residential Coal Combustion to PM 2.5 Pollution over
China's Beijing-Tianjin-Hebei Region in Winter. Atmos.Environ 159, 147-161. doi:10.1016/j.atmosenv.2017.03.054

Zhang, X., Dai, H., Jin, Y., and Zhang, S. (2019a). Evaluation of Health and Economics Benefits from "Coal to Electricity" Policy in the Residential Sector in the Jing-Jin-Ji Region. J. Peking Univ. (Natural Sciences) 55 (2), 367-376.

Zhang, X., Jin, Y., Dai, H., Xie, Y., and Zhang, S. (2019b). Health and Economic Benefits of Cleaner Residential Heating in the Beijing-TianjinHebei Region in China. Energy Policy 127, 165-178. doi:10.1016/ j.enpol.2018.12.008

Zhang, Q., Zheng, Y., Tong, D., Shao, M., Wang, S., Zhang, Y., et al. (2019c). Drivers of Improved PM2.5 air Quality in China from 2013 to 2017. Proc. Natl. Acad. Sci. U.S.A. 116 (49), 24463-24469. doi:10.1073/pnas.1907956116

Zhang, Y., Li, W., and Wu, F. (2020). Does Energy Transition Improve Air Quality? Evidence Derived from China's Winter Clean Heating Pilot (WCHP) Project. Energy 206, 118130. doi:10.1016/j.energy.2020.118130

Zhang, J. (2019a). Fellow of CEA Xie Ke Chang: We Need a Coal Revolution, but Not to Revolutionize Coal. The Paper. 24th October, 2019. Available at: https://www.thepaper.cn/newsDetail_forward_4751896 (Accessed November 6, 2019).

Zhang, J. (2019b). Deputy Direction of Electricity Department of NEA: Rural Clean Heating Is a New Thing, and it Brings Heavy Tasks. The Paper. 28th August, 2019. Available at: https://www.thepaper.cn/newsDetail_forward_4273433 (Accessed November 6, 2019).

Zhao, J., and Xue, L. (2017). The Response-Oriented Agenda-Setting Process-The Analysis Based on the Cases of Public Policy Transition in China. Cass J. Polit. Sci. (in Chinese) 3, 42-51.

Zhao, N., Zhang, Y., Li, B., Hao, J., Chen, D., Zhou, Y., et al. (2019). Natural Gas and Electricity: Two Perspective Technologies of Substituting Coal-Burning Stoves for Rural Heating and Cooking in Hebei Province of China. Energy Sci Eng 7, 120-131. doi:10.1002/ese3.263

Zhao, Y. (2021). Village Officials Coercively Removed Villagers' Heating Stoves? the Fact Tests the Wisdom of Local Governance. China Comment. Available at: http://www.banyuetan.org/jrt/detail/20210111/1000200033134991610189451759780661_ 1.html (Accessed January 25, 2021).

Zhou, L., Dai, W., Wan, S., and Ren, Q. (2018). Plans to Move Households to Clean Energy Face Challenges Again this winter. Beijing: Cainxin. Available at: https:// www.caixinglobal.com/2018-11-08/plans-to-move-households-to-clean-energyfaces-challenges-again-this-winter-101344637.html (Assessed November 6, 2019).

Zhu, H. (2017). Rural Primary Schools in Quyang County Cannot Access heating China Youth Daily. 5th December Available at: http://zqb.cyol.com/html/201712/05/nw.D110000zgqnb_20171205_6-03.htm (Assessed November 6, 2019).

Conflict of Interest: The author declares that the research was conducted in the absence of any commercial or financial relationships that could be construed as a potential conflict of interest.

Copyright () $2021 \mathrm{Hu}$. This is an open-access article distributed under the terms of the Creative Commons Attribution License (CC BY). The use, distribution or reproduction in other forums is permitted, provided the original author(s) and the copyright owner(s) are credited and that the original publication in this journal is cited, in accordance with accepted academic practice. No use, distribution or reproduction is permitted which does not comply with these terms. 